\title{
ENZYMATIC HYDROLYSIS OF WHEAT STRAW IN A STIRRED -TANK REACTOR
}

\author{
by \\ Ejaz Khan \\ Bachelor of Chemical Engineering, \\ Punjab University, Lahore, PAKISTAN, 1994
}

A project report presented to Ryerson University in partial fulfillment of the requirements for the degree of

Master of Engineering in the program of

Chemical Engineering

Department of Chemical Engineering Ryerson University

Toronto, Ontario, Canada, 2005

(C) Ejaz Khan 2005 


\section{UMI Number: EC53028}

\section{All rights reserved \\ INFORMATION TO USERS}

The quality of this reproduction is dependent upon the quality of the copy submitted. Broken or indistinct print, colored or poor quality illustrations and photographs, print bleed-through, substandard margins, and improper alignment can adversely affect reproduction.

In the unlikely event that the author did not send a complete manuscript and there are missing pages, these will be noted. Also, if unauthorized copyright material had to be removed, a note will indicate the deletion.

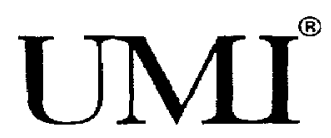

UMI Microform EC53028

Copyright 2008 by ProQuest LLC

All rights reserved. This microform edition is protected against unauthorized copying under Title 17, United States Code.

ProQuest LLC

789 East Eisenhower Parkway

P.O. Box 1346

Ann Arbor, MI 48106-1346 


\section{Author's Declaration}

I hereby declare that I am the sole author of this report.

I authorize Ryerson University to lend this report to other institutions or individuals for the purpose of scholarly research.

EJAZ KHAN

I further authorize Ryerson University to reproduce this report by photocopying or by other means, in total or parts, at the request of other institutions or individuals for the scholarly research.

EJAZ KHAN 


\begin{abstract}
In an attempt to elucidate the effect of some operating conditions on the rate and extent of enzymatic hydrolysis of lignocellulosic materials in a stirred tank reactor, wheat straw was hydrolyzed by mixing with two pitched-blade impellers mounted on a shaft under various atmospheric conditions: static air in headspace, $\mathrm{N}_{2}$ gas flowing over the surface of the medium, and minimal static air by a lid touching the surface of the medium. The presence of $\mathrm{N}_{2}$ gas over the reaction medium produced the highest $6.9 \%(\mathrm{w} / \mathrm{w})$ conversion in 36 hours. The initial conversion when $\mathrm{N}_{2}$ gas flowed in the headspace (2.9 $\% \mathrm{w} / \mathrm{w})$, and when a lid was used $(2.9 \% \mathrm{w} / \mathrm{w})$ as compared to conversion in air presence $(2.3 \% \mathrm{w} / \mathrm{w})$, seems to indicate that the enzyme activity was affected due to oxidation in the presence of air. The observed low conversion yield was probably the result of the non sterile conditions imposed by industrial requirements for the production of biofuel ethanol from agricultural lignocellulosics.
\end{abstract}




\section{Acknowledgements}

First and foremost, I would like to thank my supervisor, Dr. Ginette Turcotte, for her guidance, expertise and encouragement, and especially for believing in my potential and providing priceless training opportunities in research as well as communication skills; I am forever grateful.

I would also like to thank Mr. John Morrisson, for kindly providing us wheat straw. I am also truly grateful to all the faculty members in the program of Chemical Engineering. Funding of this research was provided by grants awarded to Dr. Ginette Turcotte from the Natural Sciences and Engineering Research Council of Canada (NSERC).

I am especially indebted to my parents Mr. \& Mrs. Mukhtar Khan, brother Iftikhar Khan, wife Riffat Ejaz and two young sons Ramis Hassan Khan and Ahmad Ejaz Khan for their love and understanding of my neglect of them during the busy time. 


\section{Table of Contents}

Author's Declaration $\quad$ ii

Abstract

Acknowledgements $\quad$ iv

Table of Contents $\quad$ v

List of Figures vii

List of Tables viii

$\begin{array}{llr}\text { Chapter } 1 & \text { Introduction } & 1\end{array}$

$\begin{array}{lll}\text { Chapter } 2 & \text { Literature Review } & 4\end{array}$

2.1 Cellulosic Feedstocks 4

2.2 Enzymatic Hydrolysis of Cellulose $\quad 6$

$\begin{array}{lll}2.3 \text { Cellulases } & 7\end{array}$

2.4 Mixing Impellers $\quad 8$

2.5 Hydrolysis and Operating Conditions 9

$\begin{array}{lll}\text { Chapter } 3 & \text { Material and Methods } & 12\end{array}$

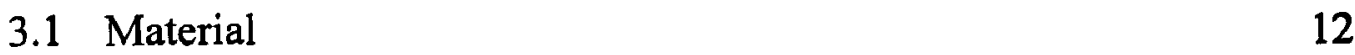

3.2 Enzymatic Hydrolysis in Three Headspace 14 Configurations

3.3 Reducing Sugar Concentration $\quad 16$ 
$\begin{array}{lll}3.5 & \text { Statistical Analysis } & 18\end{array}$

$\begin{array}{lll}\text { Chapter } 4 & \text { Results and Discussion } & 20\end{array}$

4.1 Mixing Behavior of the Fibers in Water 20

4.2 Hydrolysis with Air in the Headspace 22

4.3 Hydrolysis with $\mathrm{N}_{2}$ Spread over the Surface of Medium 25

4.4 Enzymatic Hydrolysis with Lid Touching Surface of the 26 Medium

$\begin{array}{llr}\text { Chapter } 5 & \text { Conclusion and Recommendations } & 29\end{array}$

$\begin{array}{lll}\text { Appendix A Reactor Specifications } & 30\end{array}$

$\begin{array}{lll}\text { Appendix B Average Particle Size of Sieved Wheat Straw } & 32\end{array}$

Appendix C Determination of Reducing Sugars 36

References 43 


\section{List of Figures}

$\begin{array}{lll}\text { Figure 2.1 Structure of cellulose } & 5\end{array}$

$\begin{array}{lll}\text { Figure } 3.1 & \text { Stirred tank reactor } & 15\end{array}$

Figure 4.1 Average fiber length of wheat straw $(5 \%, w / v)$ in buffer solution 21 before mixing

$\begin{array}{lll}\text { Figure } 4.2 \quad \text { Mixing behavior of } 2.56 \mathrm{~mm} \text { and } 0.84 \mathrm{~mm} \text { fiber length } & 21\end{array}$

Figure 4.3 Enzymatic hydrolysis of wheat straw with air in the headspace 23

Figure 4.4 Enzymatic hydrolysis of wheat straw with regular addition of 24 $\mathrm{NaN}_{3}$ in the presence of air in the headspace

Figure 4.5 Enzymatic hydrolysis of wheat straw with $\mathrm{N}_{2}$ spread over the 26 surface of medium

Figure 4.6 Enzymatic hydrolysis of wheat straw with restricted air 


\section{List of Tables}

Table 2.1 Enzyme specific activities in the conversion of lignocellulose to

glucose

Table 3.1 Reactor Specifications

14 


\section{Chapter 1 - Introduction}

Energy consumption has increased steadily over the last century as the world population has grown and more countries have become industrialized. Crude oil has been the major resource to meet the increased energy demand. Campbell and Laherrere (1998) estimated known crude oil reserves and reserves as yet undiscovered in the world and concluded that the decline in worldwide oil production will begin before 2010. According to them, the annual global oil production would decline from the current 25 billion barrels to approximately 5 billion barrels in 2050. Because the economy in the US and many other nations depend on oil, the consequences of inadequate oil availability could be severe. Therefore, there is a great deal of interest in exploring alternative energy sources.

Bioethanol derived from lignocellulosic residues has been receiving a lot of attention as of late. The existence of an abundant low-valued feedstock for the production of fuel grade ethanol is indeed raising the importance of its utilization. Governments in countries without or with limited deposits of crude oil are especially interested in the potential of such an endeavour for reason of national security (Wyman, 1996). Environmentalists view bioethanol as an environmentally friendlier alternative to the combustion of fossil fuels, although some consider it as a non-renewable commodity whose negative impact on the environment was calculated as several times larger than those of traditional fossil fuels (Patzek, 2004).

Some of the strongest arguments for ethanol come in its potential to provide cleaner burning fuels. Not only are carbon dioxide emissions decreased but ethanol on the whole burns cleaner than conventional gasoline. Its oxygen content helps gasoline burn more efficiently, cutting tailpipe pollutants including carbon monoxide and benzene. Even the addition of $10 \%$ ethanol to conventional gasoline can cut carbon monoxide emissions by $20 \%$, benzene emissions by $25 \%$ and overall gasoline toxicity by $30 \%$ (Putsche and Sandor, 1996). Bioethanol is not only a possible alternative to a looming energy crisis, it holds the key to a likely solution as well (Szengyel, 2000). 
The conversion of lignocellulosic biomass to fermentable sugars for the production of ethanol is nothing new. Various processes have been around for well over hundred years now. Acidic hydrolysis is usually a faster reaction than enzymatic hydrolysis (Sheehan and Himmel, 1999), but the later option has other advantages. For instance, the hydrolysis can be performed in milder conditions, which consumes less energy (Ye and Chang, 2002). Also, the amount of waste to be disposed of is significantly reduced, which lessens not only an economical burden but also environmental concerns (Howard et al., 2003).

Bioethanol can be produced from lignocellulosic materials (e.g., agricultural residues, trees and used paper) and from various plant materials (e.g., corn and wheat). Wheat straw is an abundant source of biomass readily available as agricultural residue. Because its cellulose content is high (roughly $34 \mathrm{wt}$ \% dry weight) it is a good source of sugars in the bioprocess for ethanol for use as a fuel extender (Alfani et al., 2000).

When ethanol is produced through enzymatic hydrolysis, the extent of cellulose hydrolysis by cellulase enzymes is influenced by many substrate and enzyme related factors (Esteghlalian et al., 1999). The high cost of the enzyme is a major factor in preventing the possibility of feasible process for hydrolysis (Mielenz, 2001). Thus the effective utilization of enzyme is very important. This can be achieved by using adequate mixing to ensure sufficient contact between substrate and enzyme (Hanna et al., 2001) and by providing the environmental conditions in which the enzyme remain stable and hydrolyzes maximum amount of substrate (Ganesh et al., 2000). In this way the amount of enzyme per gram of substrate can be reduced and hence, reduce the cost of the enzymatic process.

When ethanol is produced by the catalytic action of enzyme, stability and access of enzyme to substrate is important for enhanced reaction rate. So stirring must be provided to promote contact between the enzyme and substrate in an environment favorable for its activity. The aim of this study is to investigate the effect of various operating conditions during the enzymatic hydrolysis of wheat straw in a stirred tank reactor. The use of axial 
flow impellers at moderate speed was expected to helpful in lowering shear inactivation of enzymes. 


\section{Chapter 2 - Literature Review}

Although enzymatic hydrolysis of lignocellulose for the production of bioethanol has been greatly improved by new technologies, there are still challenges that need further investigations. These challenges include maintaining a stable performance of enzymes and yeast, development of more efficient pre-treatment technologies for lignocellulosic biomass. Since the stirring is a prerequisite also for the hydrolysis in pure aqueous medium to create homogeneous dispersion of the two phases in the reactor (Maria et al., 2001) and the enzyme activity is influenced by the condition of production. So the investigation of favorable mixing pattern and environmental conditions for enzyme stability is crucial in order to make process economical. To address these challenges, a good understanding of the fundamentals of the process, past discoveries and achievements is important. Therefore, this section reviews the understanding of lignocellulose, cellulases and their effective utilization during hydrolysis.

\subsection{Cellulosic Feedstocks}

Cellulosic materials are comprised of lignin, hemicellulose, and cellulose and are thus sometimes called lignocellulosic materials. One of the primary functions of lignin is to provide structural support for the plant. Thus, in general, trees have higher lignin contents then grasses. Unfortunately, lignin which contains no sugars, encloses the cellulose and hemicellulose molecules, making them difficult to reach. Hemicellulose is comprised of long chains of sugar molecules; but contains, in addition to glucose (a 6-carbon or hexose sugar), pentoses (5-carbon sugars). The exact sugar composition of hemicellulose can vary depending on the type of plant (Badger, 2002).

Cellulose is a linear mono-polymer chain solely comprised of D-glucose units linked to one another via $\beta-1,4$-glycosidic bonds. One chain end is termed the reducing end because the hemiacetal of the glucose molecule is able to open and expose the reducing aldehyde. The other chain end is called the non-reducing end because the one carbon in the hemiacetal is involved in the glycosidic bond, which prevents the ring from opening (Mosier et al., 1999). The adjacent glucose molecules are rotated $180^{\circ}$ relative to each 
other, and thus the repeating unit of a cellulose chain is the cellobiose unit (Figure $2.1 \mathrm{a}$ ). Native cellulose has an average degree of polymerization (DP) ranging from 7,000 to 15,000 glucose units. A shorter cellulose chain with glucose units from 3 to 12 is called cello-oligosaccharide, and chains with DP $>7$ are water-insoluble (Zhang and Lynd, 2004). Approximately 30-40 individual cellulose chains are laterally attached together through hydrogen bonds as well as van der Waals forces to form a tight linear bundle called an elementary cellulose fibril. An important feature of cellulose is that some parts of the chains within the elementary fibril exist in a highly organized crystalline structure due to inter and intra hydrogen bonds while the other parts remain in more loosely arranged amorphous structure (Figure $2.1 \mathrm{~b}$ ). The degree of crystallinity, as opposed to amorphousness, varies greatly from 0 to $100 \%$ depending on the origin of cellulose materials and their preparation methods (Bhat and Hazlewood, 2001). Most naturally occurring cellulose contains 40 to $90 \%$ crystallinity.
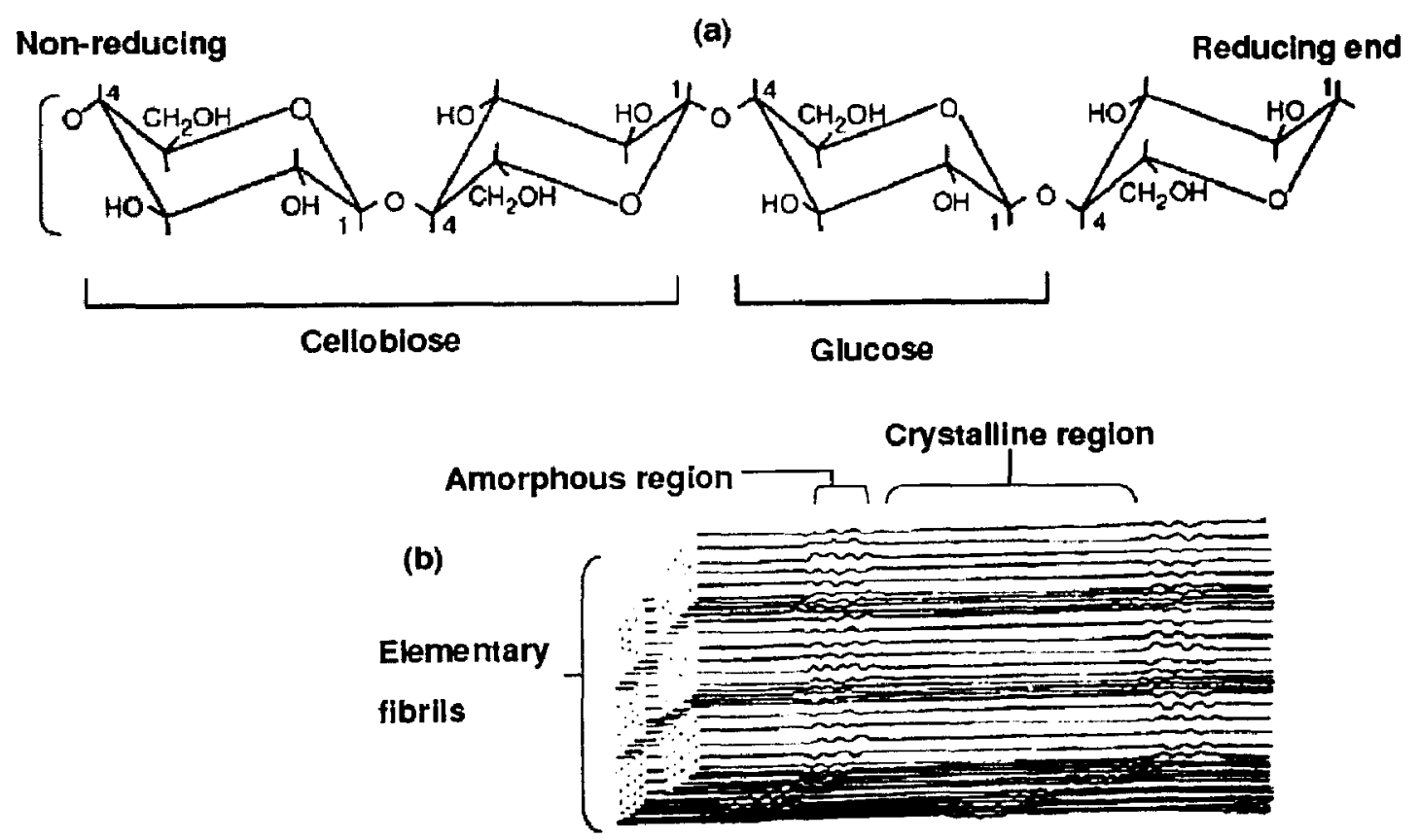

Figure 2.1 Structure of cellulose: (a) Cellobiose and glucose units, (b) Cellulose elementary fibrils with crystalline and amorphous regions (Bhat and Hazlewood, 2001). 


\subsection{Enzymatic Hydrolysis of Cellulose}

Cellulose can be hydrolyzed by many organisms including fungi and microorganisms, which produce cellulases. Unlike most other enzymatic reactions, the water-insoluble nature of cellulose necessitates the adsorption of cellulases onto the substrate prior to the hydrolysis reaction taking place (Maria et al., 2000). Upon the adsorption, cellulase hydrolyzes cellulose by cleaving the $\beta-1,4$-glucosidic bonds between glucose units in cellulose (Alfani et al., 2000). Despite this seemingly simple interaction between cellulose and cellulase, hydrolysis of cellulose is, in practice, very challenging.

The hydrolysis of cellulose can be observed in terms of the production of soluble reducing sugars such as glucose. The reaction begins with a relatively rapid increase in the yield of reducing sugars, which, however, is typically followed by a distinct slowdown of the rate of sugar production as the reaction proceeds (Mosier et al., 1999). Subsequently, the hydrolysis often stops before the substrate is completely converted into soluble sugars (Mansfield et al., 1999). Over the last few decades, many studies examined factors that limit the hydrolysis (Hatfield et al., 1999), and the recognized limiting factors include the crystalline structure, the degree of polymerization (DP), available surface area, size of cellulose substrate, enzymatic access to substrate and enzyme stability. In particular, the crystalline structure is a unique characteristic of cellulose compared to other carbohydrates, such as amylose and xylose. The cellulose chains in a crystalline structure are packed very tightly, which prevents penetration not only of enzymes but also of small molecules such as water (Lynd et al., 2002). Therefore, hydrolysis of crystalline cellulose is considered to be very difficult for cellulases. However, the relative extent to which one factor contributes to the limitation of cellulose hydrolysis compared to others is still poorly understood largely due to tremendous difficulty involved in controlling only one factor without changing the others (Zhang and Lynd, 2004). 


\subsection{Cellulases}

Cellulases are usually a mixture of several enzymes. At least three major groups of cellulases are involved in the hydrolysis process:

(1) Endoglucanase (EG, endo- 1, 4-D-glucanohydrolase) which attacks regions of low crystallinity in the cellulose fiber, creating free chain-ends.

(2) Exoglucanase or cellobiohydrolase ( $\mathrm{CBH}, 1,4-\beta$-D-glucan cellobiohydrolase) which degrades the molecule further by removing cellobiose units from the free chain-ends.

(3) $\beta$-glucosidase, which hydrolyzes cellobiose to produce glucose. In addition to the three major groups of cellulase enzymes, there are also a number of ancillary enzymes that attack hemicellulose, such as glucuronidase, acetylesterase, xylanase, $\beta$-xylosidase, galactomannanase and glucomannanase. During the enzymatic hydrolysis, cellulose is degraded by the cellulases to reducing sugars that can be fermented by yeasts or bacteria to ethanol.

Genencor's Spezyme CP gives good ethanol production rates at low to moderate enzymes loading. It is widely used for the simultaneous saccharification and fermentation (SSF) of cellulose to ethanol, contained substances inhibitory to the growth of Klebsiella Oxytoca $P \alpha$. Also Spezyme CP contains enough $\beta$-glucosidase activity to prevent cellobiose accumulation in SSF (Golias et al., 2000).

The filter paper activity assay is the most useful measure of the hydrolytic potential of cellulase preparation. The $\beta$-glucosidase (actually cellobiase) activity plays an important role in hydrolysis by relieving end product inhibition. It is not always possible to correlate $\beta$-glucosidase activity to high filter paper activity. From the data in Table 2.1, it is clear that the filter paper specific activity is highest in case of Spezyme CP, as is the carboxymethyl cellulase activity. This high CMC activity is not only important to bioethanol production but it is also essential to the food processing industry for viscosity reducing application (Nieves et al., 1998). 
Table 2.1 Enzyme specific activities in the conversion of lignocellulose to glucose

\begin{tabular}{|l|l|l|l|l|}
\hline Celulase preparation & FPU/mg & $\beta$-glucosidase U/mg & CMCU/mg & $\begin{array}{l}\text { Sold in } \\
\text { the form }\end{array}$ \\
\hline Biocellulase A & 0.24 & 0.72 & 5.5 & Liquid \\
\hline Celluclast 1.5 L & 0.37 & 0.16 & 5.1 & liquid \\
\hline Econase EC & 0.42 & 0.48 & 8.5 & liquid \\
\hline Cellulase TAP 10 & 0.13 & 5.2 & 14 & Powder \\
\hline Multifect CL (Genencor) & 0.42 & 0.20 & 7.1 & liquid \\
\hline Spezyme CP (Genencor) & 0.57 & 0.46 & 25 & liquid \\
\hline
\end{tabular}

\subsection{Mixing Impellers}

Mixers used in chemical processing have been classified primarily on the basis of the physical state and on the rheology of the substance to be mixed. The flow pattern generated by a rotating impeller at a given speed is highly dependent upon the viscosity of the liquid, high viscosities suppress the flow remote from the impeller and reduce turbulent dispersion. Thus, as a central impeller in a vessel type mixer may cause little movement of high viscosity material near the wall, the equipment must be designed to feed the material into the zone of effective mixing or the impeller must pass through the entire contents of the vessel (i.e. a large impeller to tank diameter ratio is required).

Impeller agitators are divided into two classes according the flow they generate.

- Axial flow impellers generate currents parallel with the axis of the shaft.

- Radial flow impellers generate currents tangential or radial direction (Niranjan et al., 1994).

For the simpler problems an effective agitator consists of a flat paddle turning on a vertical shaft is used. Two bladed and four bladed paddles are common. Paddles turn at slow to moderate speeds $(20-150 \mathrm{rev} / \mathrm{min})$ in the center of the vessel. Some time blades are pitched, to produce axial flow although this flow is not $100 \%$ axial flow. Axial flow 
impellers are typically high flow, low shear devices compared with the radial flow impellers. Axial flow impellers incorporate blade angles of about $45^{\circ}$ to the horizontal, although this angle can vary between $5^{\circ}$ and $60^{\circ}$. Axial flow impeller gives more mixing at a given rpm, to produce the largest amount of flow per unit horsepower as compare to radial flow (flat blade) impellers (McCabe and Smith, 1976).

The study conducted by Reese and Ryu (1980) infers that deactivating effect of shear is one of the most important factors responsible for slowing down the reaction rate during the enzymatic hydrolysis of cellulose and it must be taken into consideration for an improved equipment design. The use of angled $\left(45^{\circ}\right)$ impellers at moderate agitation for this study is an attempt to avoid shear produced by the flat blade impellers during mixing.

\subsection{Hydrolysis and Operating Conditions}

In ordinary operating conditions with an air liquid interface, the hydrolysis of the cellulose is normally facilitated by agitation. It has been shown, however, that excessive mixing can deactivate the enzymes and reduce the conversion yield. This effect has been attributed to the shear force generated by the mixer and the entrapment of air bubbles into the medium at the air-liquid surface (Mukataka et al., 1983), suggesting that cellulase activity was lost during the conversion of cellulose to glucose either because of high shear gradient near the turbine or pumping impeller, or because of thermal inactivation. It has been reported by Tanaka et al. (1986) that gas liquid interface is one of the causes of lowering of the cellulase activity during the coexistence of cellulase and substrate. Increase of agitator speed is accompanied by the increase of shearing action, and also interfacial area between the gas and liquid phases increases because of the waving of the liquid surface and the sucking of air bubbles into the liquid.

Ganesh and Joshi (2000) inferred that air liquid interface is detrimental to the enzyme activity. It was observed that loss in activity, with and without air-liquid interface was 20 $\%$ and $12.2 \%$ respectively. One such observation of increase in the stability of the enzyme with no air-liquid interface has been reported by Jones and Lee (1988) during the 
enzymatic hydrolysis of cellulose in an attrition bioreactor. Therefore, the presence of gas-liquid interface plays an important role during the enzymatic hydrolysis in stirred tank reactor.

The rate and extent of cellulose hydrolysis by cellulase enzymes is influenced by many substrate and enzyme related factors (Esteghlalian et al., 1999) including the heterogeneity of the reactants, a liquid enzyme acting upon a solid substrate. Therefore, adequate mixing is required to ensure sufficient contact between the substrate and enzymes. Mukataka et al. (1983) have shown that excessively high mixing speeds (>200 rpm) could lower the extent of cellulose conversion (Avicel and paper pulp) while moderate mixing speeds $(100-200 \mathrm{rpm})$ provide a good combination of fast initial hydrolysis rates and high conversion yields. Studies conducted by Tengborg et al. (2000) showed that while mixing speeds (paddle mixer) as high as $340 \mathrm{rpm}$ enhanced the conversion of steam-pretreated spruce wood, higher mixing speeds $(340-510 \mathrm{rpm})$ only increased the initial rate of hydrolysis. Thereafter, conversion rate leveled off, resulting in a degree of cellulose conversion similar to that obtained when agitating at $340 \mathrm{rpm}$ and described that this may be due to a decrease in enzyme activity at the higher agitation speed caused by the shear forces resulted from vigorous agitation. Shear forces may denature and damage enzymes.

Nader and Satish (1995) found that increasing the agitation speed (magnetic stirring) from 380 to $1500 \mathrm{rpm}$ increased the conversion yield of soybean hulls. This is probably due to the fact that the shear imparted by a magnetic stirrer or a shaker is much lower than that by an impeller. The enzyme stability during agitation also varies depending on the cellulase source, e.g., cellulases from $T$. reesei $\mathrm{C} 30$ were shown to be inactivated by shaking at $120 \mathrm{rpm}$, and the conversion of Avicel was even lower than that in unshaken flasks (Reese and Ryu, 1980). Also cellulases from T. reesei QM 9414 were shown to be less affected by shaking (Nader and Satish, 1995) these authors also reported a drastic decline of conversion yield in the experiments that were not conducted in a sterile environment. The utilization of glucose for growth of bacterial culture present in the 
reactor was expected to be the cause of declining glucose concentration after reaching a peak.

Intermittent mixing regimes that combine intervals of no-mixing with short periods of high or low speed mixing can benefit the enzymatic hydrolysis process by reducing energy consumption and limiting enzyme inactivation due to lower shearing of the reaction mixture, while providing reasonably high conversion yields (Tengborg et al., 2000). However, there is little information on cellulase stability in the stirred tanks that are generally used in the laboratory and industry.

Based on the above discussion, it is clear that operating conditions have a significant effect on the rate and extent of hydrolysis. For effective hydrolysis enzymatic access to substrate is necessary to get maximum substrate hydrolyzed. This can be achieved by providing stirring in a mixing system that ensure sufficient contact between enzymes and substrate, produce lower shear and high flow to minimize enzyme inactivation during stirring. Enzyme activity is also influenced by the presence of air over the reaction medium due to formation of air liquid interface during stirring. These conditions can lower the stability of the enzyme (enzyme denaturation or oxidation; Tengborg et al., 2000). So for an effective enzymatic hydrolysis it is necessary to provide conditions favorable for their activity.

\section{Research Objective}

In this study we wanted to investigate the extent of enzymatic hydrolysis in a stirred tank reactor in the presence of air and a condition in which air is restricted either by displacing it by flowing $\mathrm{N}_{2}$ gas over the medium or restricting it to enter the medium. Stirring with the help of two pitched blade impellers that generate axial flow and produce less shear were expected to lower the inactivation of enzyme at moderate speed. The utilization of enzyme under favorable operating condition to get maximum substrate hydrolyzed would be helpful in making the process economical. 


\section{Chapter 3 - Material and Methods}

This section provides the details all raw materials their source and equipments used to accomplish this investigation.

\subsection{Material}

\section{Substrate Mechanical Pretreatment}

Wheat straw (Soft White Superior, generously provided by Mr. John Morrisson, Cookston, Ontario) was used as substrate throughout this study. Wheat straw was chopped into pieces of approximately $6 \mathrm{~cm}$ at the Department of Agriculture, University of Guelph, using a mechanical chopper.

Fifty grams of chopped wheat straw were placed in a home blender with $1.5 \mathrm{~L}$ water. The mixture was grinded for 15 minutes by pressing grind key on blender. The thick slurry was then spread on a flat surface for air drying for about 48 hours. The dried lumps of wheat straw were then ground again in the same blender by pressing same key but without water for 10 minutes. This finer mixture was then kept in plastic containers until sieving.

Approximately $15.0 \mathrm{~g}$ of the finer mixture were placed on the top sieve (US Standard Sieve Series No. 4). This sieve was followed by sieve mesh Nos. 8, 12, 20, and 40 (lower sieve), and finally a solid pan at the bottom. According to Jud and Kononoff (1996), sieves were shaken manually to and fro 7 times then stack was tilted one quarter and shaken again 5 times. These 12 shakings constitutes 1 set. This procedure was repeated 7 times, for a total of 8 sets. Care was taken to avoid vertical motion of substrate during the shaking. The substrate was recovered from sieves (Nos. 8, 12, 20,40) was weighed. Two batches were made by mixing material from sieves Nos. 8 and 12 (Batch No. I), and from sieves Nos. 20 and 40 (Batch No. II). 
Average particle sizes for Batch No. I (2.56 mm) and Batch No. II $(0.84 \mathrm{~mm})$ was calculated using procedure described by McCabe and Smith (1976) and described in Appendix B.

\section{Enzymes}

Spezyme $\mathrm{CP}$, an enzyme produced by the controlled fermentation of Trichoderma longibrachiatum was donated by Genencor International (Rochester, NY). Spezyme CP was a liquid solution containing cellulase activity and other combined activities (hemicellulase and pectinases), with a declared global activity of $82 \mathrm{GCU} / \mathrm{ml}$. A concentration of $0.5 \mu \mathrm{L}$ Spezyme CP (recommended by Genencor) per gram of dry wheat straw was used in all experiments.

\section{Buffer}

To prepare $0.05 \mathrm{M}$ sodium acetate buffer, $6.90 \mathrm{~g}$ of sodium acetate trihydrate was dissolved in $800 \mathrm{ml}$ deionised water. The $\mathrm{pH}$ was adjusted to 5.0 using glacial acetic acid and the volume was adjusted to one liter.

\section{Reactor}

Two, $1 \mathrm{~L}$ polycarbonate (Fabco Mississauga) stirred tank reactors were constructed at Ryerson University (Figure 3.1). Each was equipped with a central shaft having two pitched blade impellers of size equal to $75 \%$ reactor inside diameter. One impeller was attached to the lower end of the shaft while the second impeller was located right above first impeller at height equal to impeller diameter. The other end of shaft was attached to a dual shaft mixer of power $1.32 \times 10^{-2} \mathrm{hp}(987010$; VWR). Four baffles were used to break vortex. Reactor specifications and power requirement (Table 1) for stirring were calculated using typical proportions given in McCabe and Smith (1976) and Walas (1990) respectively, and are shown in Appendix A. The calculated required power input was used to order motor suitable for this operation. The reactors were placed in an 
insulated water bath at $50{ }^{\circ} \mathrm{C}$ temperature using an immersion heater of power $120 \mathrm{~V}$ (1112A; VWR). The reactors were covered with lids, having a hole $(1.4 \mathrm{~cm}$ diameter) for sampling.

Table 3.1 Reactor Specifications

\begin{tabular}{|c|c|c|}
\hline Specifications & Symbol & Units \\
\hline Reactor inside diameter & $\mathrm{D}_{\mathrm{t}}$ & $9.5 \mathrm{~cm}$ \\
\hline Impeller Diameter & $\mathrm{D}_{\mathrm{a}}$ & $7.0 \mathrm{~cm}$ \\
\hline Impeller distance from bottom & $\mathrm{K}$ & $2.3 \mathrm{~cm}$ \\
\hline Impeller height & $\mathrm{E}$ & $0.9 \mathrm{~cm}$ \\
\hline Baffle length & $\mathrm{J}$ & $0.8 \mathrm{~cm}$ \\
\hline Baffle height & $\mathrm{H}$ & $2.3 \mathrm{~cm}$ \\
\hline Motor power & $\mathrm{P}$ & $1.32 \times 10^{-2} \mathrm{hp}$ \\
\hline Reactor length & $\mathrm{L}$ & $20 \mathrm{~cm}$ \\
\hline
\end{tabular}

\subsection{Enzymatic Hydrolyses in Three Headspace Configuration}

Eight hundred $\mathrm{ml} 0.05 \mathrm{M}$ acetate buffer was added in reactor and placed in water bath maintained at $50{ }^{\circ} \mathrm{C}$ temperature. The stirrer was turned on and adjusted to 25 RPM (lowest). When reactor temperature reached $50{ }^{\circ} \mathrm{C}$ (it took 70 minutes), reactor was taken out of water bath and emptied. The undesirable microbial growth was prevented by adding $\mathrm{NaN}_{3}(0.005 \% \mathrm{w} / \mathrm{w})$ at the start of run and every 12 hours afterwards. The reactor was charged $0.04 \mathrm{~g}$ of $\mathrm{NaN}_{3}, 40.00 \mathrm{~g}$ of substrate (Batch No. II) and $800 \mathrm{ml}$ of $0.05 \mathrm{M}$ acetate buffer already heated to $50{ }^{\circ} \mathrm{C}$, resulting in a $5 \%(\mathrm{w} / \mathrm{v})$ dry matter. The reactor was closed with lid, placed in water bath, stirrer was switched on and it adjusted to 135 rpm. After 15 minute of stirring a $1.5 \mathrm{ml}$ sample (time zero sample) was withdrawn, care was taken to place the tip of $1.5 \mathrm{ml}$ graduated pipette in a liquid portion of the hydrolysis medium at $3-5 \mathrm{~cm}$ from the top. Hydrolysis was performed by adding $20 \mu \mathrm{L}$ Spezyme CP. 


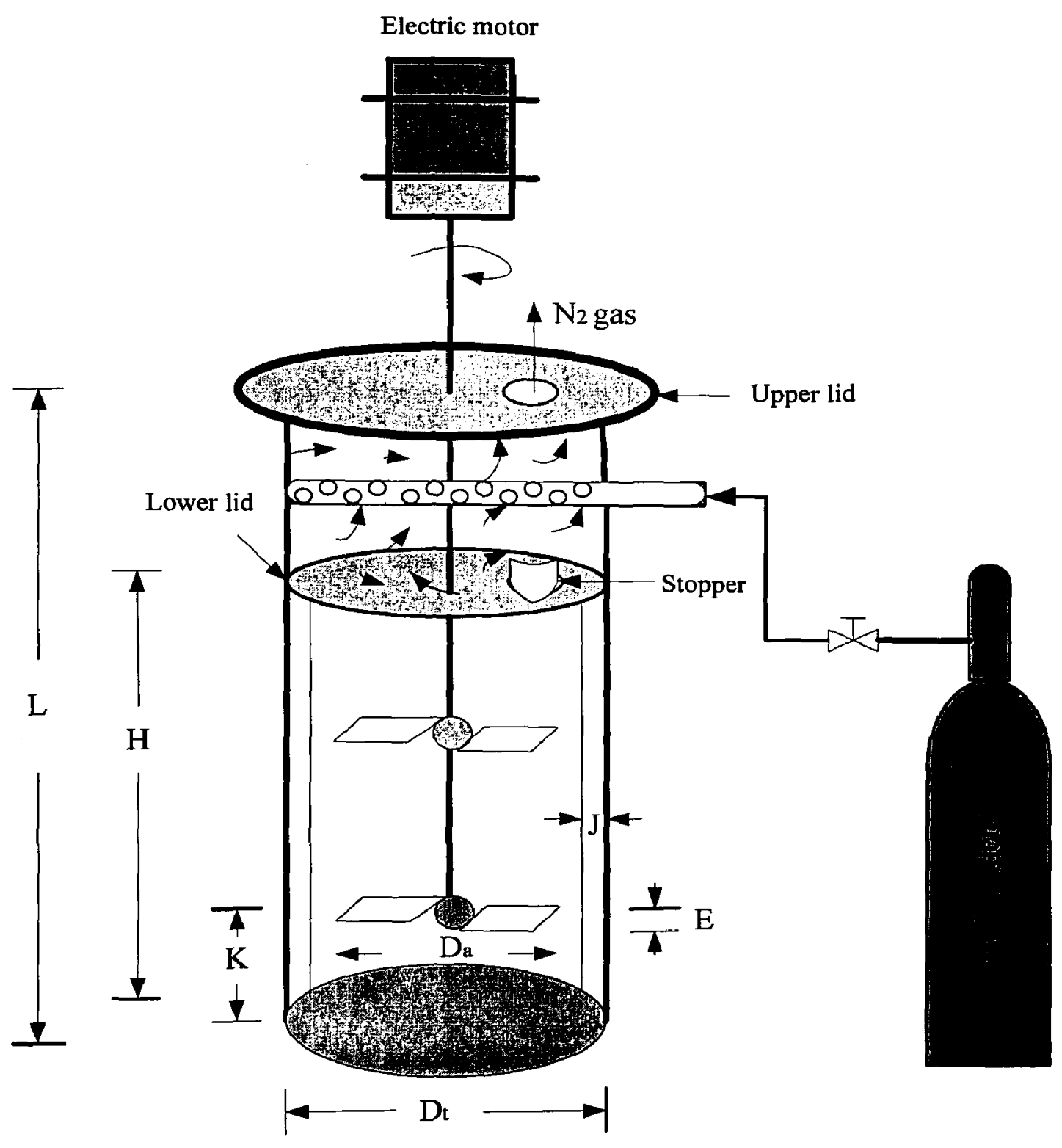

Figure 3.1 Stirred Tank Reactor (symbols were defined in Appendix A) 
A $1.5 \mathrm{ml}$ sample was withdrawn every 4 hours for 36 hours and put in microcentrifuge tubes. The samples were placed in a centrifuge at $6000 \mathrm{rpm}$ for 5 minutes at room temperature. The supernatant was frozen at $-14^{\circ} \mathrm{C}$ until determination of its reducing sugars as described later.

\section{Hydrolysis in the Presence of Air in the Headspace}

In first round of experiment the reactor was covered by only upper lid with a hole to ensure the presence of air throughout reaction time. The lid was placed on top of reactor Figure 3.1, reaction time was 36 hours and samples were withdrawn with a pipette at the start and every four hours.

\section{Hydrolysis with $\mathrm{N}_{2}$ flowing over the Medium}

Compressed $\mathrm{N}_{2}$ gas was flown over the surface of solution (Figure 3.1) at lowest possible pressure $(0.1 \mathrm{psi})$ so that no $\mathrm{N}_{2}$ gas could be felt coming out from the hole in the upper lid. $\mathrm{N}_{2}$ gas was spread with the help of perforated plastic hose inserted horizontally from side of reactor as shown in Figure 3.1. The length of perforated tube was equal to the internal diameter of reactor and closed at the end. A uniform flow of $\mathrm{N}_{2}$ gas was maintained by adjusting valve throughout the hydrolysis.

\section{Hydrolysis in the absence of Air in the Headspace}

The air was restricted by placing only lower lid right on top of the surface of solution as in shown in Figure 3.1. The sampling hole was covered with a rubber stopper.

\subsection{Reducing Sugars Concentration}

The amount of reducing sugars released from the enzymatic hydrolysis of cellulose and hemicellulose (wheat straw) was determined by a modified Dinitrosalicylic Acid (DNS) method (Wood and Bhat, 1998) where the volume of sample and of standard glucose 
solutions was $1 \mathrm{ml}$ instead of $1.5 \mathrm{ml}$. Glucose was used to generate a standard curve as shown in Appendix C.

\subsection{Hydrolysis Yield}

The hydrolysis yield compared the amount of reducing sugars experimentally released by the enzymatic hydrolysis of the cellulose and hemicellulose in wheat straw to the theoretical amount of glucose expected from the complete degradation of cellulose and hemicellulose.

Hemicellulose and cellulose are the two main structural carbohydrates of forages and straw that can be hydrolyzed into simple sugars (McDonald et al., 1991).

The hydrolysis of hemicellulose can be simplified as:

$\left[\mathrm{C}_{5}\left(\mathrm{H}_{2} \mathrm{O}\right)_{4}\right]_{\mathrm{n}}+\mathrm{nH}_{2} \mathrm{O} \rightarrow \mathrm{nC}_{5} \mathrm{H}_{10} \mathrm{O}_{5}$

hemicellulose $\quad n$ (xylose)

Cellulose, which is a homogeneous polymer (glucan), is converted into glucose, a sixcarbon monomer:

$\left[\mathrm{C}_{6}\left(\mathrm{H}_{2} \mathrm{O}\right)_{5}\right]_{\mathrm{n}}+\mathrm{nH}_{2} \mathrm{O} \rightarrow \mathrm{nC}_{6} \mathrm{H}_{12} \mathrm{O}_{6}$

cellulose glucose

The percentage of cellulose and hemicellulose in wheat straw is $34 \%$ cellulose and $25 \%$ hemicellulose, respectively (McKean et al., 1997).

In this experiment, $40 \mathrm{mg}$ wheat straw was dissolved in $800 \mathrm{ml}$ buffer, so $40 \mathrm{~g}$ of wheat straw contains cellulose $\quad=40 \times 0.34=13.6 \mathrm{~g}$ cellulose $40 \mathrm{~g}$ of wheat straw contains hemicellulose $=40 \times 0.25=10 \mathrm{~g}$ hemicellulose 
According to reaction 1, $132 \mathrm{~g}$ hemicellulose gives $150 \mathrm{~g}$ of xylose. The increase of mass of the sugar xylose (14\%) after hydrolysis with respect to the original mass of hemicellulose is due to the association of hydrogen and oxygen from water.

$10 \mathrm{~g}$ of wheat straw (hemicellulose) will hydrolyze to $=\left(\frac{150}{132}\right) \times 10$

$$
=11 \mathrm{~g} \text { of xylose }
$$

According to reaction 2, $162 \mathrm{~g}$ of cellulose gives $180 \mathrm{~g}$ of glucose. The increase of mass of the sugar glucose after hydrolysis with respect to the original mass of cellulose is 11 $\%$.

$13.6 \mathrm{~g}$ of wheat straw (cellulose) will hydrolyze to $=\left(\frac{180}{162}\right) \times 13.6$

$$
=15 \mathrm{~g} \text { of glucose }
$$

Consequently, $26 \mathrm{~g}$ of reducing sugars (xylose + glucose) are expected from the hydrolysis of $40 \mathrm{~g}$ of wheat straw, resulting in a $32.5 \mathrm{mg} / \mathrm{ml}$ reducing sugars

$$
\begin{aligned}
& =\left(\frac{26 \mathrm{gm}}{800 \mathrm{ml}}\right) \\
& =32.5 \mathrm{mg} / \mathrm{ml}
\end{aligned}
$$

The hydrolysis yield (\% conversion) will thus be reported as:

$$
\% \text { Conversion }=\frac{[\text { Experimental reducing sugars }](\mathrm{mg} / \mathrm{ml})}{32.5 \mathrm{mg} / \mathrm{ml}} 100
$$

\subsection{Statistical Analysis}

The precision of the data reported in the Results section is represented by error bars defined as: 
Confidence interval $=$ mean value $\pm 2 \times$ standard deviation (S.D)

where mean values $=$ average of duplicates for each data,

The confidential intervals from each set of data points were calculated as shown in Appendix $C$. The maximum calculated value was placed as a vertical error bar in the graph of the respective data. 


\section{Chapter 4 - Results and Discussion}

The following results report on the experimental steps taken in order to investigate the effect of some operating conditions on the extent of hydrolysis using two axial flow impellers in a stirred tank reactor.

\subsection{Mixing Behavior of the Fibers in Water}

Wheat straw with average fiber length $2.56 \mathrm{~mm}$ and $0.84 \mathrm{~mm}$, respectively, in buffer solution is shown in Figure 4.1 before mixing. The substrate in both reactors pushed upward and is floating in the upper half portion of the liquid. After 1 hour of stirring, the mixing behavior of both fibers $(2.56 \mathrm{~mm})$ and $(0.84 \mathrm{~mm})$ is shown in Figure 4.2A. The blackish portions in the medium of the left reactor represent substrate in the buffer in motion whereas the yellowish portions show stagnant substrate. From these stagnant portions substrate is moving gradually into blackish portion with stirring and some times stagnant substrate gathers on the side of reactor causing impellers to stuck in the substrate resulting in reactor to move with impeller. The movement of reactor with impeller may cause damage of impellers, reactor or motor. There is only small blackish point little above the bottom, which is showing movement of substrate in the buffer solution. This initial slower movement of the substrate might reflect the presence of a yield stress. In the right reactor of figure $4.2 \mathrm{~A}$, the use of smaller average fiber length affected the movement of the substrate, as evidenced by the distribution of blackish and yellowish portions. The lower half portion is substrate in buffer with movement whereas upper half yellowish material is stagnant with gradual movement.

After 4 hours of stirring (Figure 4.2B), only few black areas can be seen in the left reactor showing very little movement close to impellers. No up and down movement can be observed. In case of substrate having average fiber length $0.84 \mathrm{~mm}$, blackish areas can be seen in the whole volume of the solution. This shows that the substrate is moving well up and down (Figure 4.2B, right reactor). 


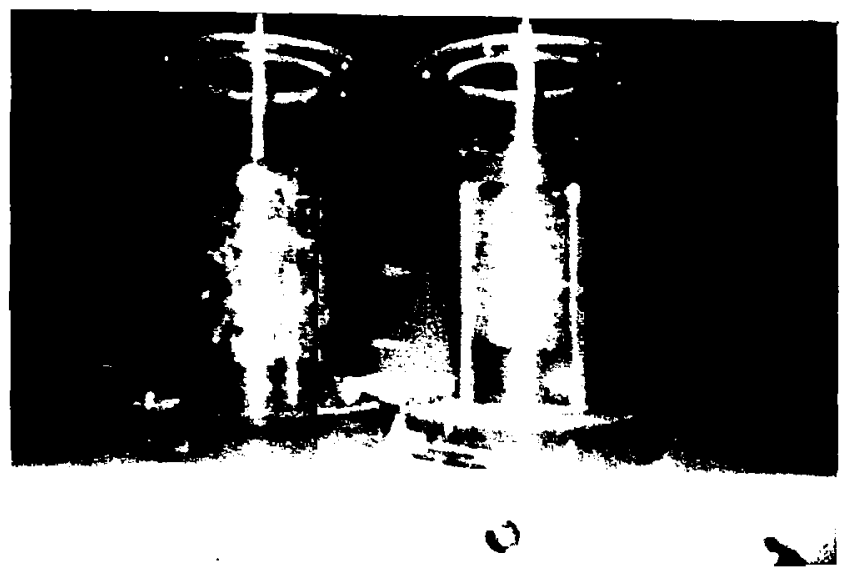

A: $2.56 \mathrm{~mm} \quad B: 0.84 \mathrm{~mm}$

Figure 4.1: Average fiber length of wheat straw (5\%, wh) in buffer solution before mixing.

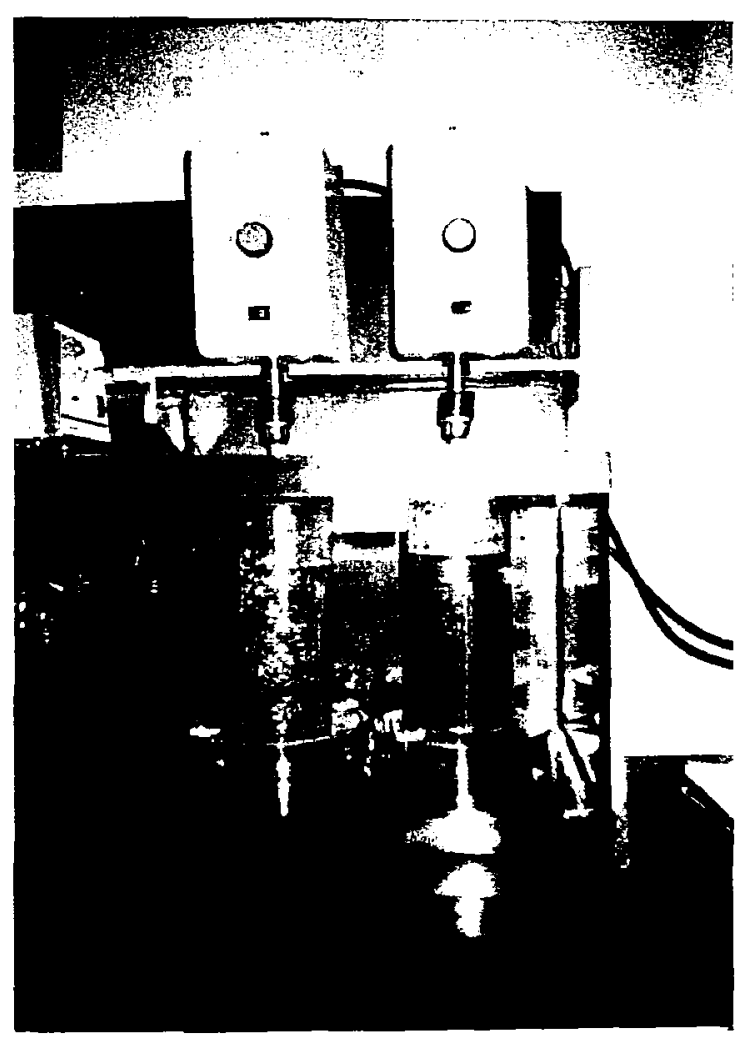

A: After I hour

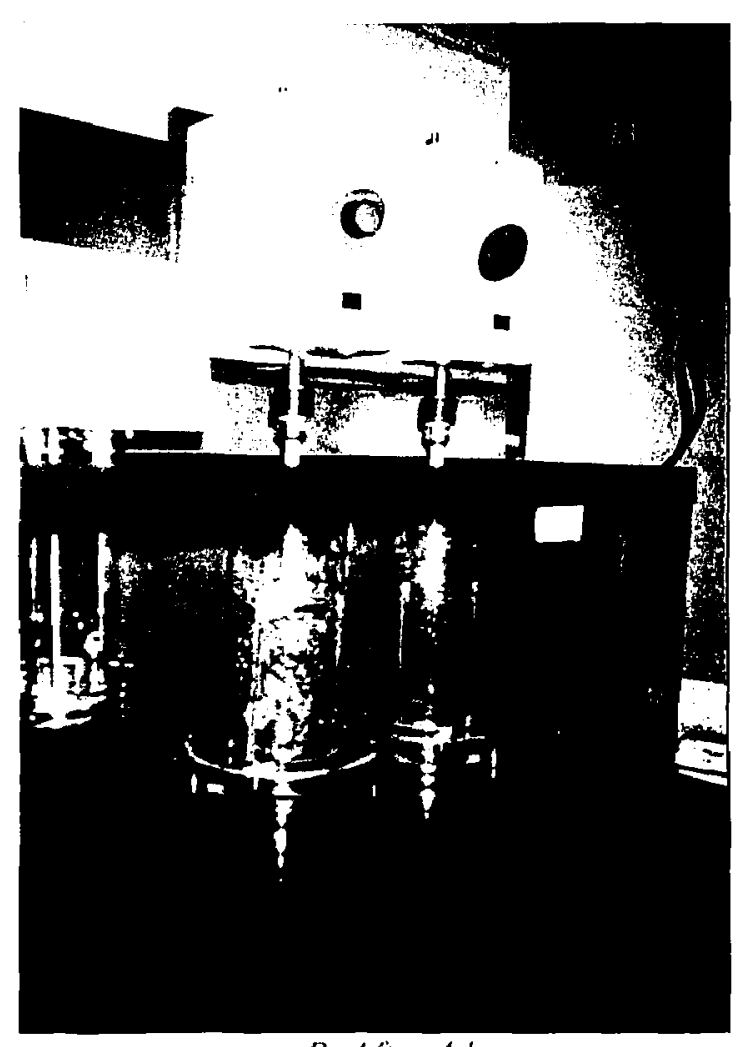

B: After 4 hour

Figure 4.2: Mixing behavior of $2.56 \mathrm{~mm}$ (left reactor) and $0.84 \mathrm{~mm}$ (right reactor) 
The use of two pitched blade impellers, which generate high flow and produce axial currents (McCabe and Smith, 1976) that cause liquid at the surface with substrate to move down and then come up, along with smaller average fiber length probably resulted a good mixing as evidence by the (Figure 4.2B, right reactor).

According to Mukataka and Tada (1983) in order to have effective hydrolysis, it is necessary to prevent stagnant points during the mixing. A recommended condition of agitation situation is, where the solid substrate move slowly and continuously in the reactor with minimum stagnant portions during hydrolysis.

In case of average wheat straw fiber length $0.84 \mathrm{~mm}$ the substrate is shown to be (Figure $4.2 \mathrm{~B}$, right reactor) moving up and down with no stagnant points that might result maximum contact between the enzyme and the substrate. So the substrate having average fiber length $0.84 \mathrm{~mm}$ was used for the hydrolysis throughout this research.

\subsection{Hydrolysis with Air in the Headspace}

The hydrolysis profile is shown in Figure 4.3. A maximum of about $3 \%$ conversion yield was achieved. The increase in conversion is gradual during the first 16 hours which reflects production of reducing sugars from wheat straw. It is probably due to presence of amorphous regions of the biomass, which are easily hydrolysable as compared to crystalline cellulose (Lynd et al., 2002) along with good mixing which is achieved in less than 4 hours, as described earlier (Figure 4.2B, right reactor), made possible for the enzymes to reach amorphous regions (Hanna et al., 2001). With air in the head space Mukataka and Tada (1983) achieved $18 \%$ conversion yield by hydrolyzing $5 \%$ pulp and paper suspension in complete fiber state during first 16 hours in an agitated reactor. The difference in conversion yield with respect to above study (Mukataka and Tada, 1983) is probably due to use of wheat straw that is composed of lignin, hemicellulose and cellulose along with non sterile conditions. The presence of lignin and hemicellulose restrict the access of enzyme to the cellulose (Sakka et al., 1996) and also reduce the cellulose crystallinity and amount of amorphous regions of the substrate (Beatriz et al., 
2004) that might lower the conversion yield. Thirdly, wheat straw was not pretreated other than grinding it. Pretreatment processes normally remove lignin and hemicellulose, reduce cellulose crystallinity, and increase the porosity of the material ( $\mathrm{Ye}$ and Cheng, 2002).

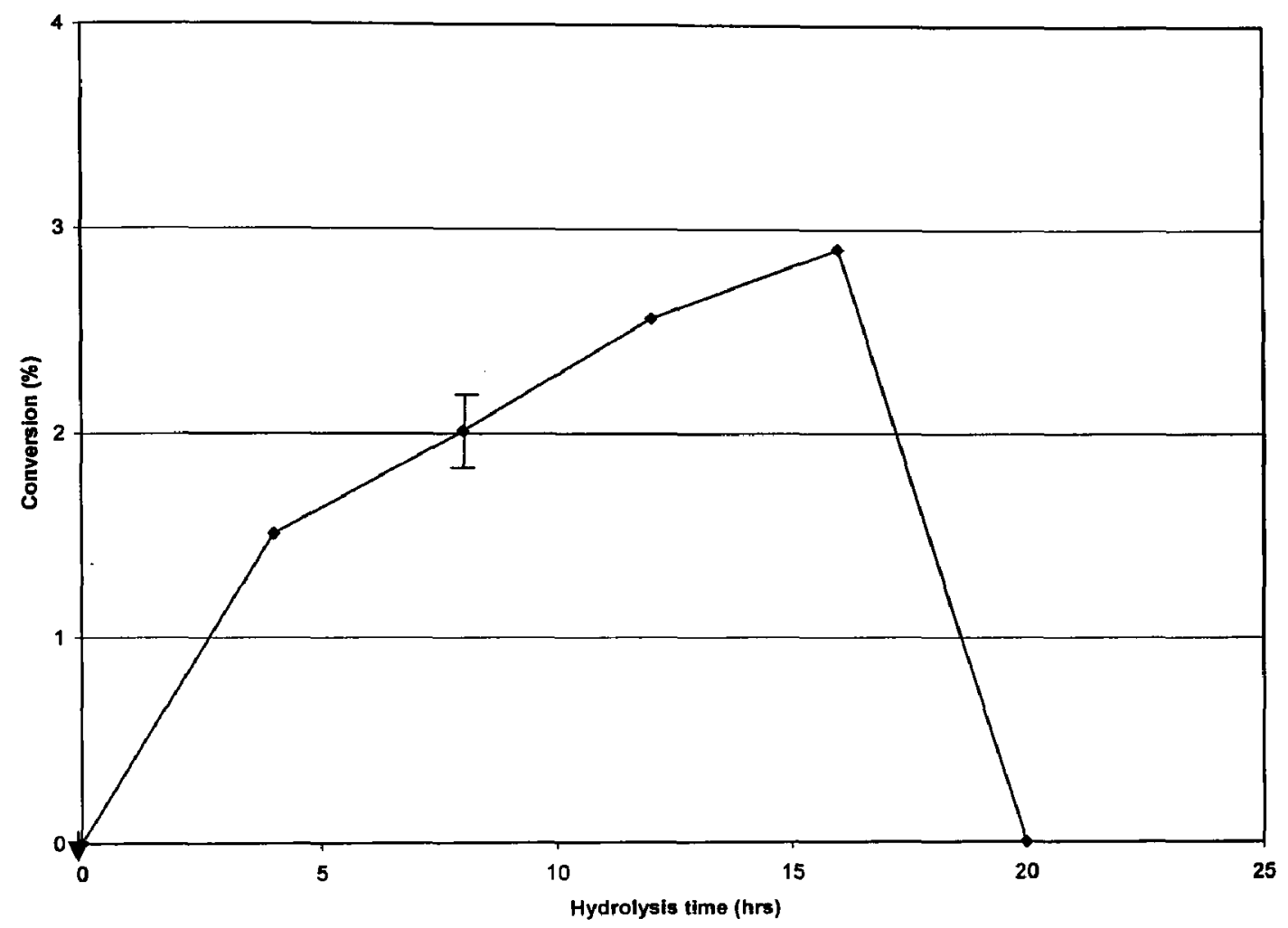

Figure 4.3 Enzymatic hydrolysis of wheat straw with air in the headspace

The sharp decrease in conversion, after 16 hours is probably due to the consumption of sugars, particularly glucose, by microbes growing in suspension despite the presence of sodium azide added at the start of the experiment. Since microbes utilize sugars faster than they are produced by the enzymatic hydrolysis, the net concentration of reducing sugars is seen sharply decreasing to zero. The amount of sodium azide might not have been sufficient to kill all microbes in the system for a long period of time. Nader and Satish (1995) also observed utilization of glucose under non sterile conditions and described that growth of microbial culture in the reactor causes the decline in glucose concentration after reaching a peak during the enzymatic saccharification of soybean hull-based material. 
It was thus decided to add sodium azide every 12 hours during the course of hydrolysis for the remainder of this study. The point of $\mathrm{NaN}_{3}$ addition is shown by arrow in all figures.

Figure 4.4 shows a replicate of Figure 4.3 when $\mathrm{NaN}_{3}$ was added after every 12 hours during the hydrolysis. A hydrolysis yield of $2.3 \%$ was achieved within 7.5 hours, which is slightly better than previously. Between 7.5 to 12 hours there was no increase in hydrolysis yield. This slowing down in reaction rate is probably due to microbial consumption of reducing sugars since the addition of $\mathrm{NaN}_{3}$ at the $12^{\text {th }}$ hour again increased the $\%$ conversion yield of hydrolysis from $2.3 \%$ to $4.2 \%$.

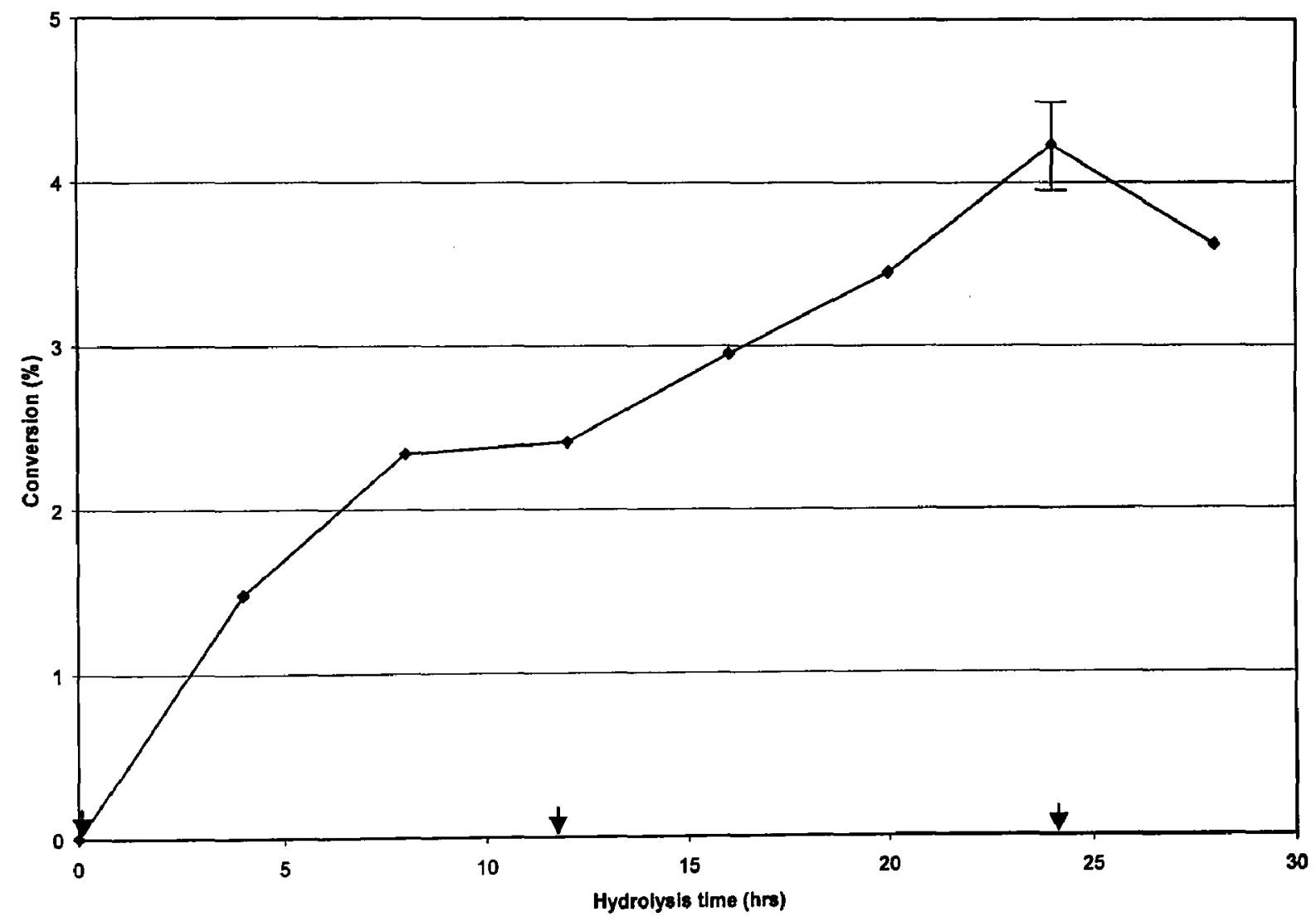

Figure 4.4 Enzymatic hydrolysis of wheat straw with regular addition of $\mathrm{NaN}_{3}$ in the presence of air in the headspace

If we compare figure 4.3 and 4.4 for the first 16 hours, \% conversion is same during this period and almost $3 \%$ conversion yield was achieved. The addition of $\mathrm{NaN}_{3}$ at $12^{\text {th }}$ hour 
helped in further increasing reaction rate even after 16 hours as compared to Figure 4.3, which shows that the argument of microbial consumption of glucose due insufficient amount $\mathrm{NaN}_{3}$ seems true. Although more $\mathrm{NaN}_{3}$ was added after 24 hours of hydrolysis, the yield declined.

Stirring and $50{ }^{\circ} \mathrm{C}$ temperature resulted in $10 \%$ liquid loss due to evaporation. So for this case maximum conversion $4.2 \%$ in actual would be $3.78 \%$.

\subsection{Hydrolysis with $\mathrm{N}_{2}$ Flown over the Surface of Medium}

When $\mathrm{N}_{2}$ gas was flown over the surface of medium, $6.9 \%$ overall conversion yield was achieved in 32 hours of hydrolysis as shown in Figure 4.5. There was $2.8 \%$ conversion in the first 7 hours, which indicate relatively increased reaction rate as compared to Figure 4.4 in which $2.3 \%$ conversion was achieved when hydrolysis was performed with air in headspace. After 7 hours, no increase in conversion yield occurred until $15^{\text {th }}$ hour.

The addition of $\mathrm{NaN}_{3}$ at the $12^{\text {th }}$ hour resulted in an increased conversion yield of about 1 $\%$ from 15 to 24 hours, whereas after 24 hours, addition of $\mathrm{NaN}_{3}$ resulted in increase of $2.7 \%$ conversion from $28^{\text {th }}$ hour to 32 hour and $6.9 \%$ conversion yield was obtained after 32 hours conversion yield declined.

One can see that the presence of $\mathrm{N}_{2}$ instead of air almost doubled the conversion yield. This is probably due to the fact that some enzymes are assumed to be inactivated by oxidation in the presence of air entrained in the medium by agitation (Mukataka and Tada, 1983). The increase of conversion yield in the presence of $\mathrm{N}_{2}$ gas over the medium contradicts results reported by Tanaka et al. (1977), who found that the presence of air and $\mathrm{N}_{2}$ over the surface of reaction medium was unrelated to cellulase inactivation. But their hydrolyses were performed in the absence of stirring. Since could be no question of aeration in stagnant medium, air could not become entrapped. 


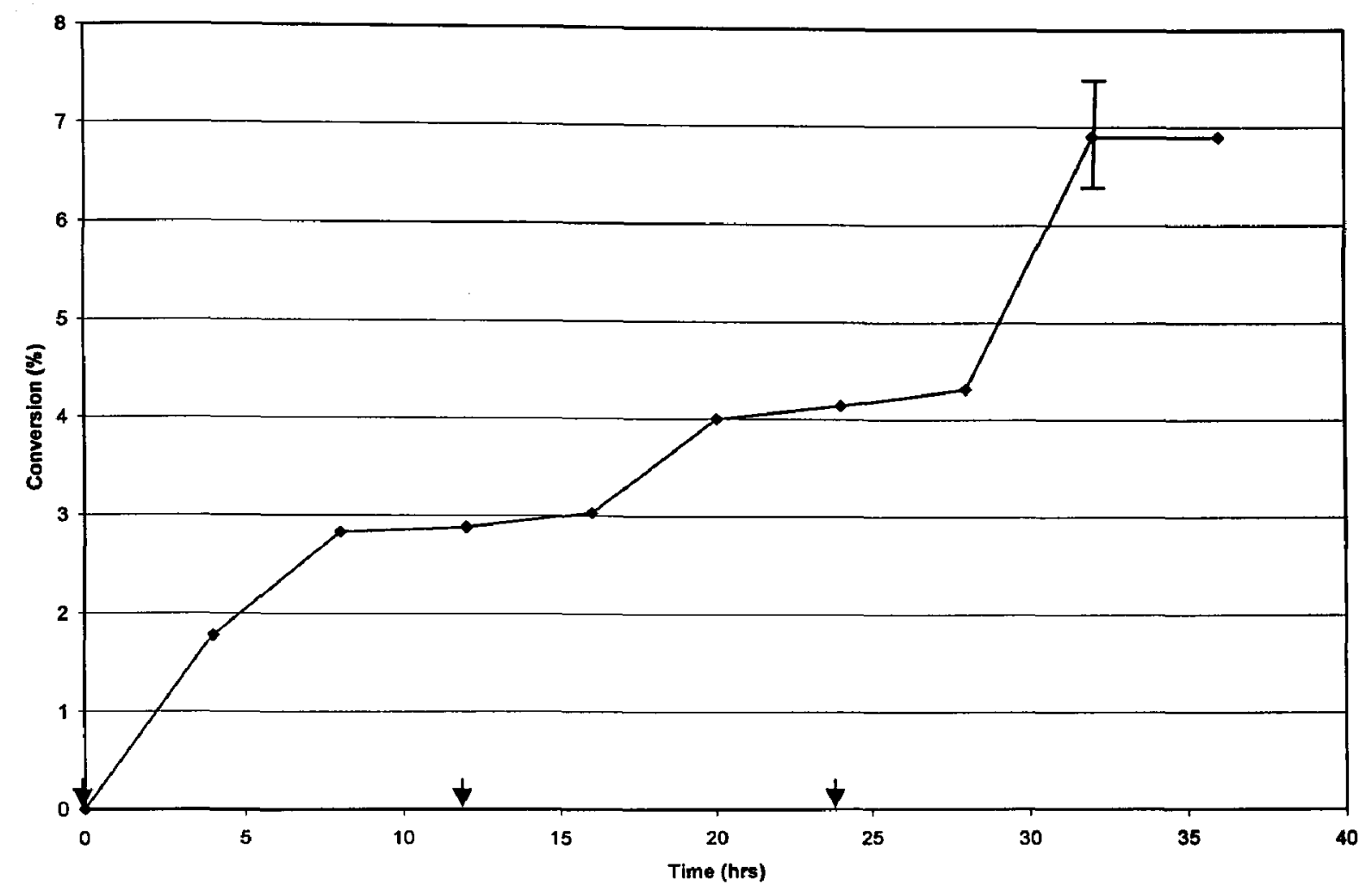

Figure 4.5 Enzymatic hydrolysis of wheat straw with $\mathrm{N}_{2}$ spread over the surface of medium

The liquid loss in this case was rapid due to $\mathrm{N}_{2}$ gas flow as compared to previous one and approximately $150 \mathrm{ml}$ liquid evaporated in 12 hours. $120 \mathrm{ml}$ buffer solution was added after every 12 hours in order to maintain liquid level well above the upper impeller. Approximately $10 \%$ solvent was lost at the end, so maximum $\%$ conversion reported 6.9 $\%$ would be $6.21 \%$ in actual.

\subsection{Hydrolysis with Lid Touching Surface of the Medium}

To separate the effect of air liquid interface and a condition in which air is restricted, hydrolysis of wheat straw was performed by placing a lid touching the surface of the medium. The results are shown in Figure 4.6. The initially the \% conversion yield was $2.9 \%$ in the first 12 hours as compared to $2.3 \%$ hydrolysis in the presence of air in headspace and $2.9 \%$ hydrolysis in the presence of $\mathrm{N}_{2}$ gas. The slight increase in conversion yield when air entrapment is restricted by a lid or by its replacement with $\mathrm{N}_{2}$ might argue in favor of enzyme stabilization or activity in the absence of contact with air. 
Ganesh and Joshi (2000) reported cellulase activity loss with and without surface aeration of 20.9 and $12.2 \%$ respectively. The trend of hydrolysis curve is quite unexpected from 12 hours to 24 hours, as in this period conversion yield increased slightly from $2.9 \%$ to 3 \%. From 24 hours to 32 hours hydrolysis yield increased from $3 \%$ to $4.2 \%$. After 32 hours there is drastic decline in the yield.

The overall conversion yield in this case was the same as when an air head space was present. Both were about the half value obtained during hydrolysis in the presence of $\mathrm{N}_{2}$ gas over the medium. This trend is probably due to the fact that system could not maintain without air throughout the hydrolysis time. The lid which was placed on the top was not sealed completely, allowing some air to enter the system. Secondly, some space over the liquid created due to evaporation of $\mathrm{H}_{2} \mathrm{O}$ during hydrolysis that might cause airhead space in the system which probably resulted aeration due to entrapment of air into medium.

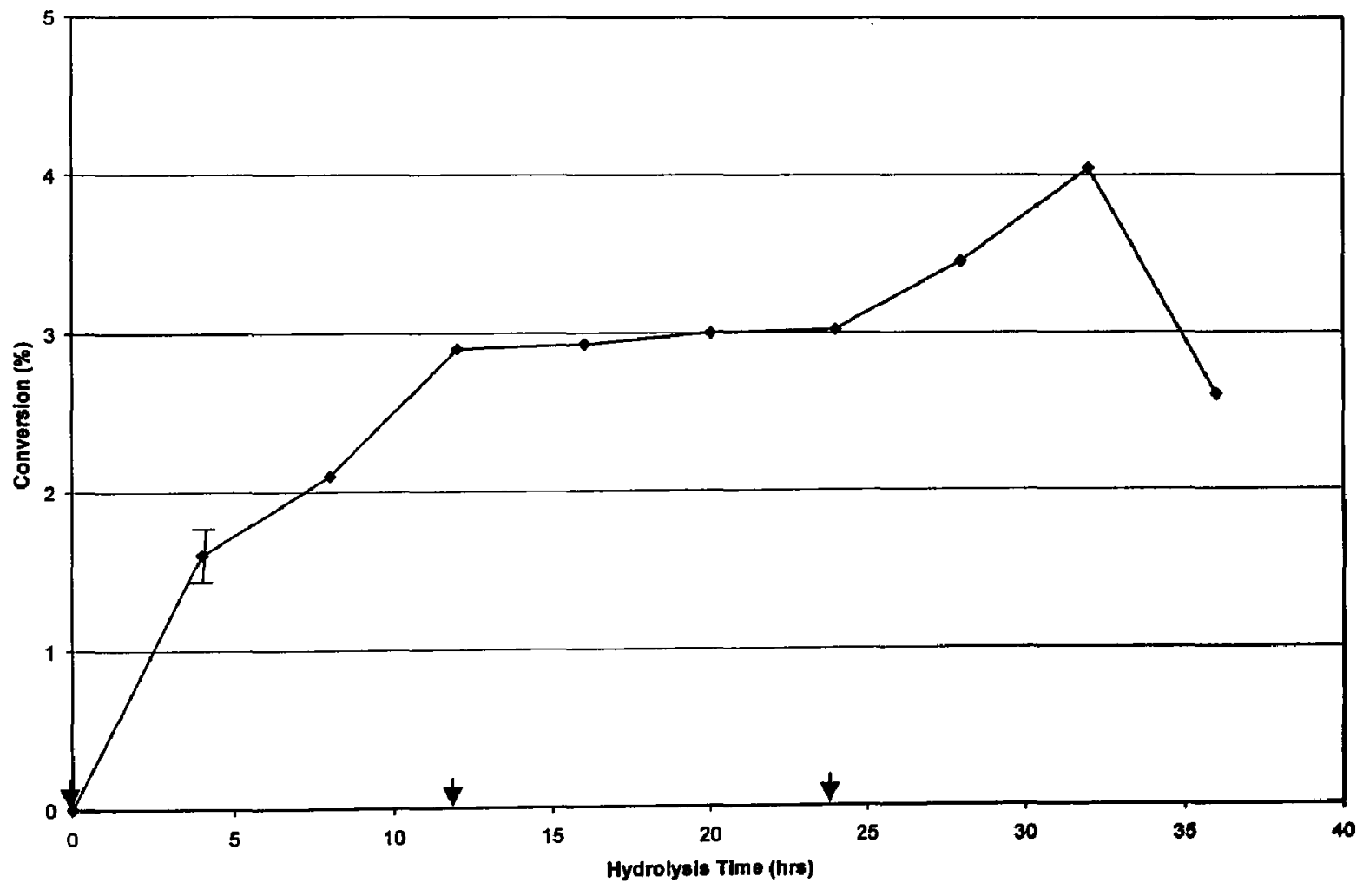

Figure 4.6 Enzymatic hydrolysis of wheat straw with restricted air 
A similar trend of substantially increased enzyme stability is also reported by James and Lee (1988) due to elimination of air-liquid interface during enzymatic hydrolysis of cellulose in an attrition bioreactor. The same initial hydrolysis in case of air restricted and in the presence of $\mathrm{N}_{2}$ gas over the medium in first 12 hours shows that replacing air from the system results in increased conversion yield. Although overall conversion yield in Figure 4.7 is less as compared to Figure 4.6 but it might be possible, that by completely restricting air from the system can result overall conversion yield close to the case where $\mathrm{N}_{2}$ gas was spread over the medium. This way cost of using $\mathrm{N}_{2}$ gas can be saved and process would be more economical.

The liquid loss was less in the presence of lid over the medium as compared to previous cases and approximately $50 \mathrm{ml}$ liquid evaporated. Maximum \% conversion reported 4.2 $\%$ would be $3.9 \%$. 


\section{Chapter 5 - Conclusion and Recommendations}

The results of this study suggested that presence of air in headspace results in loss of conversion during hydrolysis of wheat straw. The relatively high conversion yield when air displaced by flowing $\mathrm{N}_{2}$ gas through system shows that presence of air probably affected the activity of the enzymes used for the hydrolysis. The low conversion yield in presence of air as compared to $\mathrm{N}_{2}$ gas in the headspace infers that air might cause oxidation of enzyme that is probably one of the causes of enzyme inactivation. The exact cause of low yield with air in headspace is needed to be address. The relatively fast $2.9 \%$ conversion in first 12 hours of hydrolysis both in case of restricted air and $\mathrm{N}_{2}$ in headspace probably due to homogenous mixing achieved within first four hours of hydrolysis by using two pitched blade impellers.

The overall low conversion yield in case of restricted air as compared to $\mathrm{N}_{2}$ gas flowing in head is might be due to reason that air was not completely restricted, so if the hydrolysis is performed in air tight system to get conversion yield comparable with $\mathrm{N}_{2}$ gas in headspace that would help to reduce the price of $\mathrm{N}_{2}$ gas to displace air from the system.

The effect of microbial contamination was prominent in all cases, even when the $\mathrm{NaN}_{3}$ was used three times during 36 hours. So the appropriate minimum amount of $\mathrm{NaN}_{3}$ needed to address to get maximum sterile conditions. This might be achieved by reducing the duration of $\mathrm{NaN}_{3}$ addition that may be after every 6 hours.

Finally, substrate pretreatment by a feasible pretreatment method could be helpful in getting high overall conversion yield. From this study we learned, that the elimination of air from reaction medium is crucial for enzyme stability and effective mixing can help in improving enzyme activity that may result enhanced conversion yield. 


\section{Appendix A - Reactor Specifications}

Following typical proportions were used to design agitation system described by McCabe and Smith (1976).

1. Diameter of a paddle impeller is, $D_{a}$, typically $50-80$ percent of the inside diameter of the reactor: $\mathrm{D}_{\mathrm{a}}=(0.5-0.8) \mathrm{D}_{\mathrm{t}}$

$$
\begin{aligned}
& D_{t}=\text { Inside diameter of reactor } \\
& D_{\mathrm{a}}=\text { Impeller diameter }
\end{aligned}
$$

2. The width of the blade is one-sixth to one-tenth of impeller diameter,

$$
E=\left(\frac{1}{6} \text { to } \frac{1}{10}\right) D_{a}
$$

3. Impeller distance from bottom $=K=\frac{1}{6}$ (liquid height)

4. Baffle width $J=\frac{D_{t}}{12}$

5. Baffle height $=$ Liquid height in reactor

For 1 liter buffer solution, the internal diameter of the one liter beaker was calculated 10 $\mathrm{cm}$. Polycarbonate pipe ordered for reactor, available closest size was $9.5 \mathrm{~cm}$ internal diameter. Based $9.5 \mathrm{~cm}$ internal diameter, mixing system was designed described below. Internal diameter of the reactor $=D_{t}=9.5 \mathrm{~cm}$

Diameter of impeller (blade) $=D_{a}=(0.5-0.8) D_{t}$. Here used $0.75 D_{t}$

$$
\mathrm{D}_{\mathrm{a}}=0.75 \mathrm{D}_{\mathrm{t}}=7.125=7 \mathrm{~cm}
$$

The width of the blade is one-sixth to one-tenth of the impeller diameter Impeller (blade) height $=E=\left(\frac{1}{6}\right.$ to $\left.\frac{1}{10}\right) D_{a}$. Here used $\frac{1}{8} \times D_{a}$ 


$$
\mathrm{E}=\frac{1}{8} \times 7=0.875=0.9 \mathrm{~cm}
$$

Impeller (blade) height $=\mathrm{E}=0.9 \mathrm{~cm}$

Baffle width $=\mathrm{J}=\frac{\mathrm{D}_{\mathrm{t}}}{12}=\frac{9.5}{12}=0.79=0.8 \mathrm{~cm}$

Liquid height in reactor $=14 \mathrm{~cm}=$ Height of $800 \mathrm{ml}$ liquid in reactor

Impeller distance from bottom $=\frac{1}{6}$ (liquid height)

$$
\mathrm{K}=\frac{1}{6}(14)=2.3 \mathrm{~cm}
$$

Baffle height $=$ Liquid height in reactor $=\mathrm{H}=14 \mathrm{~cm}$

\section{Power input for motor}

For baffled paddle blade agitators power input for slurries $=10 \frac{\mathrm{hp}}{1000 \text { gal }}$ (Walas, 1990). This conversion factor is valid for thick slurry and was taken as an approximation for fiber suspension.

1 gallons $=3.785$ liters

1000 gallons $=3785$ liters

For

3785 liter of slurry motor power required $=10 \mathrm{hp}$

1 liter of slurry motor power required $\quad=\frac{10}{3785} \mathrm{hp}$

$$
=2.6 \times 10^{-3} \mathrm{hp}
$$




\section{Appendix B - Average Particle Size of Sieved Wheat Straw}

The average particle size of fibers was calculated using the differential method described by McCabe and Smith (1976).

\section{Average Particle Size}

The average particle size for a mixture of particles was defined in terms of volume surface mean diameter $\overline{D_{s}}$ and is related to the specific surface area $A_{w}$, according to following equation:

$$
\overline{\mathrm{D}_{\mathrm{s}}}=\frac{6}{\Phi_{\mathrm{s}} A_{\mathrm{w}} \ell_{\mathrm{p}}}
$$

Where

$\mathrm{A}_{w}=$ Specific surface, total surface of the one unit mass of sample, can be calculated by

$$
\mathrm{A}_{\mathrm{w}}=\frac{6 \Delta \phi_{1}}{\Phi_{\mathrm{s}} \ell_{\mathrm{p}} \overline{\mathrm{D}}_{1}}+\frac{6 \Delta \phi_{2}}{\Phi_{\mathrm{s}} \ell_{\mathrm{p}} \overline{\mathrm{D}}_{2}}+\cdots+-\cdots+\frac{6 \Delta \phi_{\mathrm{n}_{\mathrm{T}}}}{\Phi_{\mathrm{s}} \ell_{\mathrm{p}} \overline{\mathrm{D}}_{\mathrm{n}_{\mathrm{T}}}}
$$

Subscripts refer to the individual screen increment, $\mathrm{n}_{\mathrm{T}}$ is the number of screens.

$\ell_{\mathrm{p}}=$ Density of substrate (sieved wheat straw) $=182 \mathrm{~kg} / \mathrm{m}^{3}$

Density was calculated by filling sieved substrate in graduated cylinder.

$\Phi_{s}=$ Sphericity for crushed material is between 0.6 and 0.7 (McCabe and Smith, 1976). So an average of 0.6 and $0.7=0.65$ was used in calculation.

Density $\ell_{\mathrm{p}}$ and sphericity $\Phi_{\mathrm{s}}$ are known, so it was assumed that these quantities are independent of particle diameter. For a mixture containing particles of various sizes, the average diameter may differ widely from one another (McCabe and Smith, 1976). 
Some fibers that were larger than the diameter of the hole size passed through the screen, since light fibers can position themselves vertically (Lammers et al., 1996). To calculate the average diameter of particles at a specific mesh size, an assumption is made that all particles in a single fraction, which is obtained on any mesh after shaking, are equal in size and that the size is the arithmetic mean of the mesh dimensions of the two screens that define the fraction (McCabe and Smith, 1976). Thus, the mesh dimensions of No.4 and No.8 mesh are $4.75 \mathrm{~mm}$ and $2.36 \mathrm{~mm}$ respectively. Consequently, the $4 / 8$ fraction is assumed to consist of uniform particles of diameter, $\frac{4.75+2.36}{2}=3.55 \mathrm{~mm}$

Here 4/8 means that the particle fraction passed through mesh No. 4 and was retained on mesh No. 8. Similarly, fraction $8 / 12$ has an average diameter of:

$$
\frac{2.36+1.69}{2}=2.02 \mathrm{~mm}
$$

So we have,

Fraction I (4/8) of particles having average diameter $\quad=D_{1}=3.55 \mathrm{~mm}$

Fraction II (8/12) of particles having average diameter $\quad=\mathrm{D}_{2}=2.02 \mathrm{~mm}$

Fraction III (12/20) of particles having average diameter $=\mathrm{D}_{3}=1.25 \mathrm{~mm}$

Fraction IV (20/40) of particle having average diameter $=D_{4}=0.629 \mathrm{~mm}$

Using this sieve method, two batches were made as shown in Table B1.

Table B1. Substrate fractions from sieves

\begin{tabular}{|c|c|c|c|}
\hline Batch No. I & $\begin{array}{c}\text { Quantity } \\
\text { (gram) }\end{array}$ & Batch No. II & $\begin{array}{c}\text { Quantity } \\
\text { (gram) }\end{array}$ \\
\hline Fraction I (4/8) & 20.00 & Fraction III (12/20) & 20.00 \\
\hline Fraction II (8/12) & 20.00 & Fraction IV (20/40) & 20.00 \\
\hline Total weight & 40.00 & Total weight & 40.00 \\
\hline
\end{tabular}


Average fiber size of sieved wheat straw collected from mesh No. 8 and 12 calculated as

Fraction I (4/8) $\quad \mathrm{D}_{1}=3.55 \mathrm{~mm}$

Fraction II (8/12) $\quad \mathrm{D}_{2}=2.02 \mathrm{~mm}$

$\Delta \phi=$ Mass fraction of sample that is retained on a particular screen.

$\Delta \phi_{\mathrm{I}}=\frac{20}{40}=0.5$

$\Delta \phi_{\mathrm{II}}=\frac{20}{40}=0.5$

Specific surface of mixture

From equation 2

$A_{\mathrm{w}}=\frac{6 \times 0.5}{0.65 \times 182 \frac{\mathrm{kg}}{\mathrm{m}^{3}} \times 0.0035 \mathrm{~m}}+\frac{6 \times 0.5}{0.65 \times 182 \frac{\mathrm{kg}}{\mathrm{m}^{3}} \times 0.0020 \mathrm{~m}}$
$\mathrm{A}_{w}=7.2455+12.5236$
$A_{\mathrm{w}}=19.7964 \mathrm{~m}^{2} / \mathrm{kg}$

Corresponding average fiber length from equation 1

$\overline{D_{s}}=\frac{6}{0.65 \times 19.7964 \frac{\mathrm{m}^{2}}{\mathrm{~kg}} \times 182 \frac{\mathrm{kg}}{\mathrm{m}^{3}}}$

$\bar{D}_{s}=0.00256 \mathrm{~m}=2.56 \mathrm{~mm}$ 
Similarly for fractions collected from sieves with mesh No. 20 and 40.

Fraction III (12/20) $\quad D_{3}=1.25 \mathrm{~mm}$

Fraction IV (20/40) $\quad D_{4}=0.629 \mathrm{~mm}$

$\Delta \phi_{1}=\frac{20}{40}=0.5$

$\Delta \phi_{2}=\frac{20}{40}=0.5$

$A_{\mathrm{w}}=\frac{6 \times 0.5}{0.65 \times 182 \frac{\mathrm{kg}}{\mathrm{m}^{3}} \times 1.25 \times 10^{-3} \mathrm{~m}}+\frac{6 \times 0.5}{0.65 \times 182 \frac{\mathrm{kg}}{\mathrm{m}^{3}} \times 6.29 \times 10^{-4}}$

$A_{\mathrm{w}}=20.04+40.25$

$A_{\mathrm{w}}=60.2978 \mathrm{~m}^{2} / \mathrm{kg}$

Also, $\bar{D}_{\mathrm{s}}$ using equation (1)

$\overline{\mathrm{D}}_{\mathrm{s}}=\frac{6}{0.65 \times 182 \frac{\mathrm{kg}}{\mathrm{m}^{3}} \times 60.2978 \frac{\mathrm{m}^{2}}{\mathrm{~kg}}}$

$\overline{\mathrm{D}_{\mathrm{s}}}=0.84 \mathrm{~mm}$ 


\section{Appendix C - Determination of Reducing Sugars}

\section{Reducing sugars concentration and percentages of hydrolysis yield determination by DNS method}

A modified procedure of Wood \& Bhat (1998) was followed to make a standard curve from a $2 \mathrm{mg} / \mathrm{ml}$ standard solution and to calculate the amount of reducing sugar released during the enzymatic hydrolysis. $0.2000 \mathrm{gm}$ of glucose (dextrose) was weighed and added to $100 \mathrm{ml}$ distilled water, resulting in a $2.00 \mathrm{mg} / \mathrm{ml}$ solution. A similar procedure was used to prepare standard solution containing $0.000,0.040,0.080$, and $0.120 \mathrm{gm} / \mathrm{ml}$.

One millilitre of each solution was placed in a test tube, $3 \mathrm{ml}$ of the DNS reagent, was added, and mixed. All tubes were placed in a boiling water bath for 5 minutes, insuring that each test tube content was completely immersed in water. After 5 minutes, the test tubes were cooled to room temperature and $15 \mathrm{ml}$ distilled water added to each test tube. A UV Spectrophotometer was used at a wavelength of $540 \mathrm{~nm}$. Two samples, as reference were used from a solution of distilled water plus DNS that was subjected to boiling, cooling and adding $15 \mathrm{ml} \mathrm{H}_{2} \mathrm{O}$. Read the absorbance of solution at $540 \mathrm{~nm}$.

A standard curve was produced from the experimental data shown Table $\mathrm{C} 1$. The dots in the figure correspond to the mean value of the duplicates shown in the table.

Table C 1. Data for DNS standard curve

\begin{tabular}{|c|c|c|c|c|}
\hline \multicolumn{2}{|c|}{ Absorbanc } & $10 \mathrm{~nm}$ & & \multirow[b]{2}{*}{$\begin{array}{l}\text { Standard } \\
\text { Deviation }\end{array}$} \\
\hline $\begin{array}{c}\text { [Glucose] } \\
(\mathrm{mg} / \mathrm{ml})\end{array}$ & $1^{\text {st }}$ set & $2^{\text {nd }}$ set & Mean value & \\
\hline 0.0 & 0.0173 & 0.0174 & 0.01735 & 0.0000 \\
\hline 0.04 & 0.2595 & 0.2370 & 0.2482 & 0.0111 \\
\hline 0.08 & 0.5942 & 0.5960 & 0.5951 & 0.0009 \\
\hline 0.12 & 0.9205 & 0.9124 & 0.9164 & 0.0040 \\
\hline
\end{tabular}




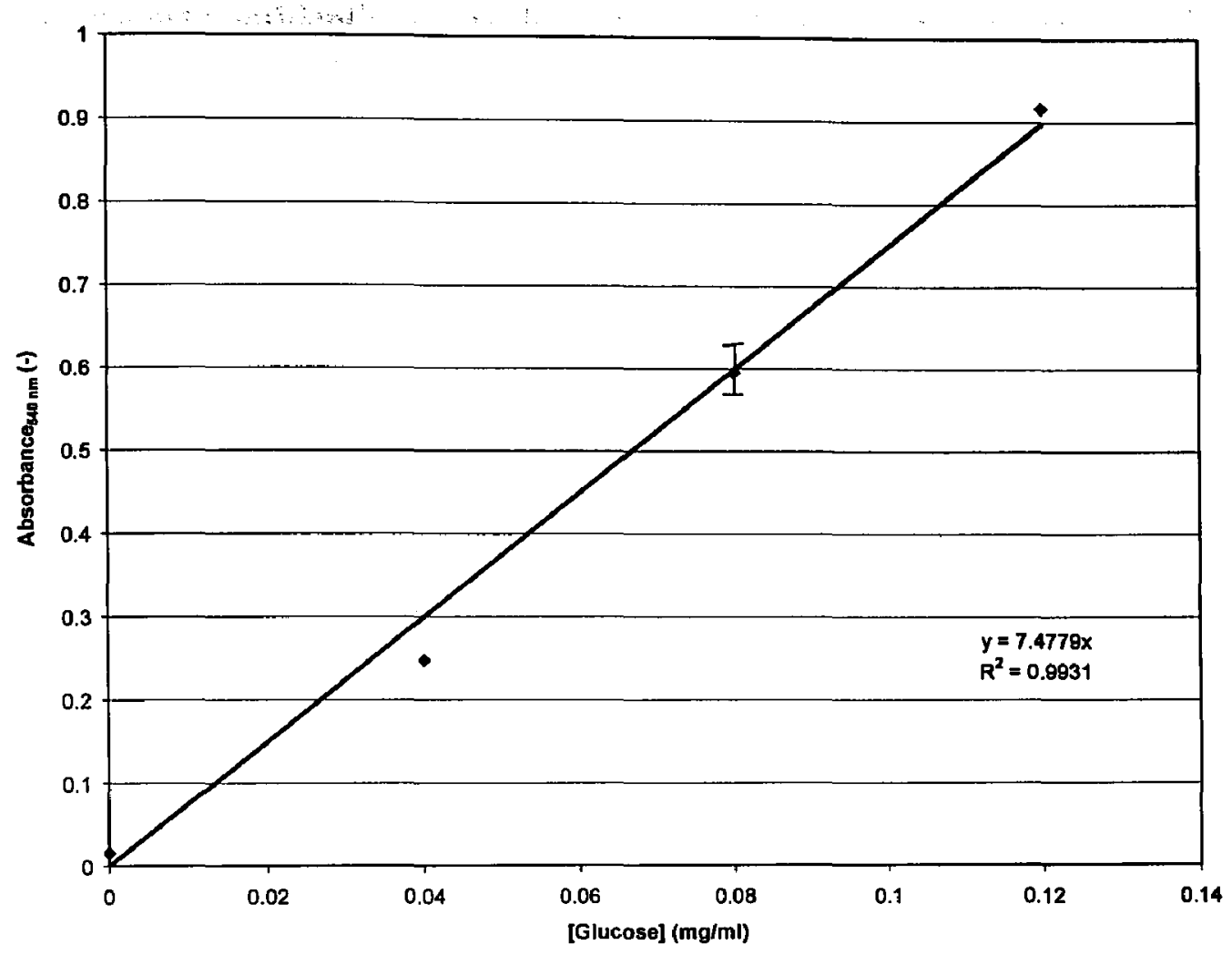

Figure C1. DNS standard curve for reducing sugar concentration

Standard deviation of $1^{\text {st }}$ set for second point:

SD was calculated by using equation given below (Murray et al., 2000):

$\mathrm{SD}=\sqrt{\frac{(\mathrm{x}-\overline{\mathrm{x}})^{2}}{(\mathrm{n}-1)}}$

$\bar{x}=$ Mean value

$n=$ Number of values

$\mathrm{SD}=\sqrt{\frac{(0.2595-0.2482)^{2}}{(2-1)}}=0.011$

Standard deviation of $2^{\text {nd }}$ set for second point:

$\mathrm{SD}=\sqrt{\frac{(0.2370-0.2482)^{2}}{(2-1)}}=0.011$ 
Mean SD for these two points $=0.011$

The greatest confidential intervals from each set of data points are presented in figure $\mathbf{C l}$.

Confidence interval $=$ mean value $\pm 2 \times$ standard deviation

$$
=0.2482 \pm 2(0.011)
$$

The deviation is usually calculated for a large population but that, for a sample s.d., 4 points is usually the minimum. Here we have 2 points (one for each duplicate run), and that only gives a crude approximation of the true statistic.

\section{Experimental data for reducing sugars and hydrolysis yield}

The tables below contain raw data for reducing sugars analysis and derived data of hydrolysis yield. Conversion from reducing sugar concentration to percentage of hydrolysis yield was done by the equation given in section 3.4.

Table C 2. Absorbance and reducing sugars measured when hydrolysis in the presence of air in the headspace.

\begin{tabular}{|c|c|c|c|c|c|c|}
\hline \multirow{2}{*}{ Hydrolysis } & First & run & Second & run & \multirow{3}{*}{$\begin{array}{c}\text { Mean } \\
\text { Absorbance }\end{array}$} & \multirow{3}{*}{$\begin{array}{c}\text { Mean } \\
\text { reducing } \\
\text { sugars }\end{array}$} \\
\hline & & & & & & \\
\hline Time & $\begin{array}{c}\text { Absorbance } \\
540 \mathrm{~nm}\end{array}$ & $\begin{array}{c}\text { Reducing } \\
\text { sugars }\end{array}$ & $\begin{array}{c}\text { Absorbance } \\
540 \mathrm{~nm}\end{array}$ & $\begin{array}{l}\text { Reducing } \\
\text { sugars }\end{array}$ & & \\
\hline (hrs) & $(-)$ & $(\mathrm{mg} / \mathrm{ml})$ & $(-)$ & $(\mathrm{mg} / \mathrm{ml})$ & $(-)$ & $\overline{(\mathrm{mg} / \mathrm{ml})}$ \\
\hline 0 & 0.0440 & 0.002 & 0.0440 & 0.002 & 0.0440 & 0.002 \\
\hline 4 & 0.2590 & $\overline{0.030}$ & 0.2590 & 0.031 & 0.2590 & 0.030 \\
\hline 8 & 0.3810 & 0.045 & 0.3801 & 0.041 & 0.3805 & 0.043 \\
\hline 12 & 0.4312 & 0.059 & 0.4312 & 0.059 & 0.4312 & 0.059 \\
\hline 16 & 0.4524 & 0.06 & 0.4524 & 0.060 & 0.4524 & 0.060 \\
\hline 20 & 0.00 & 0.00 & 0.00 & 0.00 & 0.00 & 0.00 \\
\hline 24 & 0.00 & 0.00 & 0.00 & 0.00 & 0.00 & 0.00 \\
\hline
\end{tabular}


Table C 3. Hydrolysis yield of wheat straw with air in the headspace

\begin{tabular}{|c|c|c|c|c|c|c|}
\hline $\begin{array}{c}\text { Hydrolysis } \\
\text { Time }\end{array}$ & $\begin{array}{c}\text { First run } \\
\text { Conversion }\end{array}$ & $\begin{array}{c}\text { Second run } \\
\text { Conversion }\end{array}$ & $\begin{array}{c}\text { Absorbance } \\
\text { at } 540 \mathrm{~nm}\end{array}$ & $\begin{array}{c}\text { Glucose } \\
\text { Concentration }\end{array}$ & $\begin{array}{c}\text { Mean } \\
\text { Conversion }\end{array}$ & $\begin{array}{c}\text { Standard } \\
\text { Deviation }\end{array}$ \\
\hline$(\mathrm{hrs})$ & $(\%)$ & $(\%)$ & $(-)$ & $(\mathrm{mg} / \mathrm{ml})$ & $(\%)$ & $(\%)$ \\
\hline 0 & 0.00 & 0.00 & 0.044 & 0.002 & 0.00 & 0.00 \\
\hline 4 & 1.47 & 1.52 & 0.259 & 0.031 & 1.50 & 0.025 \\
\hline 8 & 2.21 & 2.01 & 0.383 & 0.041 & 2.11 & 0.10 \\
\hline 12 & 2.90 & 2.90 & 0.431 & 0.059 & 2.90 & 0.00 \\
\hline 16 & 3.00 & 2.90 & 0.452 & 0.060 & 2.95 & 0.05 \\
\hline 20 & 0.00 & 0.00 & 0.00 & 0.00 & 0.00 & 0.00 \\
\hline 24 & 0.00 & 0.00 & 0.00 & 0.00 & 0.00 & 0.00 \\
\hline
\end{tabular}

Table C 4. Absorbance and reducing sugars measured when hydrolysis by regular addition of $\mathrm{NaN}_{3}$ in the presence of air in the headspace

\begin{tabular}{|c|c|c|c|c|c|c|}
\hline \multirow[b]{2}{*}{ Hydrolysis } & First & run & \multirow{2}{*}{\multicolumn{2}{|c|}{ Second }} & \multirow{3}{*}{$\begin{array}{c}\text { Mean } \\
\text { Absorbance }\end{array}$} & \multirow{3}{*}{$\begin{array}{c}\text { Mean } \\
\text { Reducing } \\
\text { Sugars }\end{array}$} \\
\hline & & & & & & \\
\hline Time & Absorbance & $\begin{array}{c}\text { reducing } \\
\text { sugars }\end{array}$ & Absorbance & $\begin{array}{c}\text { reducing } \\
\text { sugars }\end{array}$ & & \\
\hline (hrs) & $(-)$ & $(\mathrm{mg} / \mathrm{ml})$ & $(-)$ & $(\mathrm{mg} / \mathrm{ml})$ & $(-)$ & $(\mathrm{mg} / \mathrm{ml})$ \\
\hline 0 & 0.0440 & 0.002 & 0.0440 & 0.002 & 0.0440 & 0.0025 \\
\hline 4 & 0.2590 & 0.030 & 0.2570 & 0.031 & 0.2580 & 0.0305 \\
\hline 8 & 0.3810 & 0.045 & 0.4300 & 0.050 & 0.4055 & 0.047 \\
\hline 12 & 0.4312 & 0.059 & 0.2896 & 0.039 & 0.3604 & 0.049 \\
\hline 16 & 0.4524 & 0.06 & 0.4524 & 0.060 & 0.4524 & 0.060 \\
\hline 20 & 0.5378 & 0.07 & 0.5378 & 0.070 & 0.5378 & 0.070 \\
\hline 24 & 0.6550 & 0.082 & 0.6697 & 0.090 & 0.6623 & 0.086 \\
\hline
\end{tabular}


Table C 5. Hydrolysis by regular addition of $\mathrm{NaN}_{3}$ in the presence of air in the headspace

\begin{tabular}{|c|c|c|c|c|c|c|}
\hline $\begin{array}{c}\text { Hydrolysis } \\
\text { Time }\end{array}$ & $\begin{array}{c}\text { First run } \\
\text { Conversion }\end{array}$ & $\begin{array}{c}\text { Second run } \\
\text { Conversion }\end{array}$ & $\begin{array}{c}\text { Mean } \\
\text { Absorbance } \\
\text { at 540 nm }\end{array}$ & $\begin{array}{c}\text { Mean } \\
\text { Glucose } \\
\text { Concentration }\end{array}$ & $\begin{array}{c}\text { Mean } \\
\text { Conversion }\end{array}$ & $\begin{array}{c}\text { Standard } \\
\text { Deviation }\end{array}$ \\
\hline$(\mathrm{hrs})$ & $(\%)$ & $(\%)$ & $(-)$ & $(\mathrm{mg} / \mathrm{ml})$ & $(\%)$ & $(\%)$ \\
\hline 0 & 0.00 & 0.00 & 0.044 & 0.0025 & 0.00 & 0.00 \\
\hline 4 & 1.47 & 1.50 & 0.2580 & 0.030 & 1.48 & 0.015 \\
\hline $\mathbf{8}$ & 2.21 & 2.46 & 0.4055 & 0.047 & 2.34 & 0.125 \\
\hline 12 & 2.90 & 1.92 & 0.3604 & 0.049 & 2.41 & 0.49 \\
\hline 16 & 2.95 & 2.95 & 0.4524 & 0.060 & 2.95 & 0.00 \\
\hline 20 & 3.45 & 3.45 & 0.5378 & 0.070 & 3.45 & 0.00 \\
\hline 24 & 4.04 & 4.43 & 0.6623 & 0.086 & 4.23 & 0.195 \\
\hline
\end{tabular}

Table C 6. Absorbance and concentration measured when hydrolysis with $\mathbf{N}_{\mathbf{2}}$ flown over the surface of medium

\begin{tabular}{|c|c|c|c|c|c|c|}
\hline \multirow[b]{2}{*}{ Hydrolysis } & First & run & Second & run & \multirow{3}{*}{$\begin{array}{c}\text { Mean } \\
\text { Absorbance }\end{array}$} & \multirow{3}{*}{$\begin{array}{c}\text { Mean } \\
\text { Reducing } \\
\text { Sugars }\end{array}$} \\
\hline & & & & & & \\
\hline Time & Absorbance & $\begin{array}{l}\text { reducing } \\
\text { sugars }\end{array}$ & Absorbance & $\begin{array}{l}\text { reducing } \\
\text { sugars }\end{array}$ & & \\
\hline (hrs) & $(-)$ & $(\mathrm{mg} / \mathrm{ml})$ & $(-)$ & $(\mathrm{mg} / \mathrm{ml})$ & $(-)$ & $(\mathrm{mg} / \mathrm{ml})$ \\
\hline 0 & 0.0440 & 0.002 & 0.0440 & 0.002 & 0.044 & 0.0025 \\
\hline 4 & 0.2679 & 0.035 & 0.2789 & 0.037 & 0.2734 & 0.036 \\
\hline 8 & 0.4300 & 0.058 & 0.4106 & 0.057 & 0.4206 & 0.057 \\
\hline 12 & 0.4310 & 0.058 & 0.4312 & 0.059 & 0.4311 & 0.058 \\
\hline 16 & 0.4525 & 0.061 & 0.4526 & 0.062 & 0.4525 & 0.061 \\
\hline 20 & 0.6000 & 0.080 & 0.5900 & 0.078 & 0.5950 & 0.079 \\
\hline 24 & 0.6667 & 0.085 & 0.6429 & 0.083 & 0.6548 & 0.084 \\
\hline 28 & 0.6667 & 0.085 & 0.6697 & 0.090 & 0.6682 & 0.087 \\
\hline 32 & 0.7743 & 0.150 & 0.7640 & 0.130 & 0.7691 & 0.14 \\
\hline 36 & 0.7743 & 0.150 & 0.7640 & 0.130 & 0.7690 & 0.14 \\
\hline
\end{tabular}


Table C 7. Hydrolysis yield of wheat straw with $\mathrm{N}_{2}$ flown over the surface of medium

\begin{tabular}{|c|c|c|c|c|c|c|}
\hline $\begin{array}{c}\text { Hydrolysis } \\
\text { Time }\end{array}$ & $\begin{array}{c}\text { First run } \\
\text { Conversion }\end{array}$ & $\begin{array}{c}\text { Second run } \\
\text { Conversion }\end{array}$ & $\begin{array}{c}\text { Absorbance } \\
\text { at } 540 \mathrm{~nm}\end{array}$ & $\begin{array}{c}\text { Mean } \\
\text { Glucose } \\
\text { Concentration }\end{array}$ & $\begin{array}{c}\text { Mean } \\
\text { Conversion }\end{array}$ & $\begin{array}{c}\text { Standard } \\
\text { Deviation }\end{array}$ \\
\hline$(\mathrm{hrs})$ & $(\%)$ & $(\%)$ & $(-)$ & $(\mathrm{mg} / \mathrm{ml})$ & $(\%)$ & $(\%)$ \\
\hline 0 & 0.00 & 0.00 & 0.044 & 0.0025 & 0.00 & 0.00 \\
\hline 4 & 1.72 & 1.82 & 0.2734 & 0.036 & 1.78 & 0.050 \\
\hline 8 & 2.85 & 2.81 & 0.4206 & 0.057 & 2.83 & 0.020 \\
\hline 12 & 2.85 & 2.9 & 0.4311 & 0.058 & 2.88 & 0.025 \\
\hline 16 & 3.00 & 3.05 & 0.4525 & 0.061 & 3.03 & 0.025 \\
\hline 20 & 3.94 & 3.84 & 0.5950 & 0.079 & 4.00 & 0.16 \\
\hline 24 & 4.18 & 4.1 & 0.6548 & 0.084 & 4.14 & 0.04 \\
\hline 28 & 4.18 & 4.43 & 0.6682 & 0.087 & 4.31 & 0.125 \\
\hline 32 & 7.40 & 6.40 & 0.7691 & 0.14 & 6.9 & 0.50 \\
\hline 36 & 7.40 & 6.40 & 0.7690 & 0.14 & 6.9 & 0.50 \\
\hline
\end{tabular}

Table C 8. Absorbance and concentration measured when hydrolysis with lid touching surface of the medium

\begin{tabular}{|c|c|c|c|c|c|c|}
\hline \multirow[b]{2}{*}{ Hydrolysis } & First & run & Second & run & \multirow{3}{*}{$\begin{array}{c}\text { Mean } \\
\text { Absorbance }\end{array}$} & \multirow{3}{*}{$\begin{array}{l}\text { Mean } \\
\text { reducing } \\
\text { Sugars }\end{array}$} \\
\hline & & & & & & \\
\hline Time & Absorbance & $\begin{array}{l}\text { reducing } \\
\text { sugars }\end{array}$ & Absorbance & Concentration & & \\
\hline (hrs) & $(-)$ & $(\mathrm{mg} / \mathrm{ml})$ & $(-)$ & $(\mathrm{mg} / \mathrm{ml})$ & $(-)$ & $(\mathrm{mg} / \mathrm{ml})$ \\
\hline 0 & 0.0440 & 0.002 & 0.0440 & 0.002 & 0.044 & 0.0025 \\
\hline 4 & 0.2679 & 0.035 & 0.2590 & 0.030 & 0.2634 & 0.0325 \\
\hline 8 & 0.3800 & 0.040 & 0.3810 & 0.045 & 0.3805 & 0.0425 \\
\hline 12 & 0.4310 & 0.058 & 0.4413 & 0.059 & 0.4361 & 0.0585 \\
\hline 16 & 0.4413 & 0.059 & 0.4450 & 0.060 & 0.4431 & 0.0595 \\
\hline 20 & 0.4525 & 0.061 & 0.4566 & 0.062 & 0.4545 & 0.0627 \\
\hline 24 & 0.4526 & 0.062 & 0.4525 & 0.061 & 0.4525 & 0.0615 \\
\hline 28 & 0.5378 & 0.070 & 0.5378 & 0.070 & 0.5378 & 0.070 \\
\hline 32 & 0.6649 & 0.081 & 0.6667 & 0.085 & 0.6658 & 0.083 \\
\hline
\end{tabular}


Table C 9. Hydrolysis yield of wheat straw with lid touching surface of the medium

\begin{tabular}{|c|c|c|c|c|c|c|}
\hline $\begin{array}{c}\text { Hydrolysis } \\
\text { Time }\end{array}$ & $\begin{array}{c}\text { First run } \\
\text { Conversion }\end{array}$ & $\begin{array}{c}\text { Second run } \\
\text { Conversion }\end{array}$ & $\begin{array}{c}\text { Absorbance } \\
\text { at } 540 \mathrm{~nm}\end{array}$ & $\begin{array}{c}\text { Mean } \\
\text { Glucose } \\
\text { Concentration }\end{array}$ & $\begin{array}{c}\text { Mean } \\
\text { Conversion }\end{array}$ & $\begin{array}{c}\text { Standard } \\
\text { Deviation }\end{array}$ \\
\hline$(\mathrm{hrs})$ & $(\%)$ & $(\%)$ & & $(\mathrm{mg} / \mathrm{ml})$ & $(\%)$ & $(\%)$ \\
\hline 0 & 0.00 & 0.00 & 0.044 & 0.0025 & 0.00 & 0.00 \\
\hline 4 & 1.72 & 1.48 & 0.2634 & 0.0325 & 1.6 & 0.12 \\
\hline 8 & 2.00 & 2.20 & 0.3805 & 0.0425 & 2.1 & 0.1 \\
\hline 12 & 2.90 & 2.90 & 0.4361 & 0.0585 & 2.9 & 0.00 \\
\hline 16 & 2.90 & 3.00 & 0.4431 & 0.0595 & 2.93 & 0.1 \\
\hline 20 & 3.00 & 3.05 & 0.4545 & 0.0627 & 3.00 & 0.025 \\
\hline 24 & 3.05 & 3.00 & 0.4525 & 0.0615 & 3.02 & 0.025 \\
\hline 28 & 3.45 & 3.45 & 0.5378 & 0.070 & 3.45 & 0.00 \\
\hline 32 & 4.00 & 4.18 & 0.6658 & 0.083 & 4.15 & 0.09 \\
\hline
\end{tabular}




\section{References}

Alfani, F., A. Gallifuoco and A. Spera (2001). "Comparison of SHF and SSF processes for the bioconversion of steam-exploded wheat straw". Journal of Industrial Microbiology \& Biotechnology, 25, 184-192.

Badger, P.C. (2002). "Ethanol from cellulose: A general review". In Janick, J. and A. Whipkey (eds.), Trends in New Crops and New Uses, ASHS Press, Alexandria, VA, 1721.

Beatriz, P.A., T. Juhasz., M. Galbe and G. Zacchi (2004). "Hydrolysis of nonstarch carbohydrates of wheat-starch effluent for ethanol production". Biotechnology Progress, $20,474-479$.

Beguin, P. and J. P. Aubert (1994). "The biological degradation of cellulose". FEMS Microbiology Review, 13, 25-58.

Bhat, M.K. and G.P. Hazlewood (2001). "Enzymology and other characteristics of cellulases and xylanases". In Bedford, M.R. and G.G. Partridge (eds), Enzymes in Farm Animal Nutrition, CABI Publishing, Wiltshire, 11-60.

Campbell, C.J. and J.H. Laherrere (1998). "The end of cheap oil". Scientific American, 3, 78-83.

Esteghlalian, A., V. Srivastava., N. Gilkes., D.J. Gregg and J.N. Saddler (1999). “An overview of factors influencing the enzymatic hydrolysis of lignocellulosic feedstocks", In Himmel, E.H., J.O. Baker., J.N. Saddler (eds), Glycosyl Hydrolases for Biomass Conversion, American Chemical Society, Washington, 6, 100-111.

Ganesh, K., J.B. Joshi and S.B. Sawant (2000). "Cellulase deactivation in a stirred reactor". Biochemical Engineering Journal, 4, 137-141. 
Golias, H., G. J. Dumsday., G. A. Stanley and N. B. Pamment (2000). "Characteristics of cellulase preparations affecting the simultaneous saccharification and fermentation of cellulose to ethanol". Biotechnology Letters, 22, 617-621.

Hanna, I., G. Zacchi., B. Yang and R. Ali (2001). "The effect of shaking regime on the rate and extent of enzymatic hydrolysis of cellulose". Journal of Biotechnology, 88, 177182.

Hatfield, R.D., J. Ralph and J.H. Grabber (1999). "Cell wall structural foundations: molecular basis for improving forage digestibilities". Crop Science, 39, 27-37.

Howard, R.L., E. Abotsi, E.L. Jansen and S. Howard (2003). "Lignocellulose biotechnology: issues of bioconversion and enzyme production". African Journal of Biotechnology, 2, 602-613.

Jones, E.O. and M.J. Lee (1988). "Kinetic analysis of bioconversion of cellulose in an attrition bioreactor". Biotechnology Bioengineering, 31, 35-40.

Jud, H. and P. Kononoff (1996). "Evaluating particle size of forages and TMRs using the new Penn State forage particle separator". Dairy and Animal Science, 02(42), 1-15.

Lammers, B.P., D.R. Buckmaster and A.J. Heinrichs (1996). "A simple method for the analysis of particle sizes of forages and total mixed rations". Journal of Dairy Science, 79, 922-928.

Lynd, R.L., P.J. Weimer, W.H. Zyl, and I.S. Pretorius (2002). "Microbial cellulose utilization: fundamentals and biotechnology". Microbiology and Molecular Biology Reviews, 66, 506-577.

Mansfield, S.D., C. Mooney and J.N. Saddler (1999). "Substrate and enzyme characteristics that limit cellulose hydrolysis". Biotechnology Progress, 15, 804-816. 
Maria, C., F. Alfani., L. Cantarella., A. Gallifuoco and A. Saporosi (2001). "Biosaccharification of cellulosic biomass in immiscible solvent-water mixtures". Journal of Molecular Catalysis B: Enzymatic, 11, 867-875.

Mark, F.D. and M.L. James (1985). "Enzymatic hydrolysis of cellulosic substances in an attrition bioreactor". Biotechnology and Bioengineering Symposium, 5, 277-293.

McCabe, W.L. and J.C. Smith (1976). "Unit Operations of Chemical Engineering". ${ }^{\text {rd }}$ edition. McGraw-Hill Kogakusha, Ltd. 9, 221-264.

McDonald, P., A.R Henderson and S.J.E. Heron (1991). "The Biochemistry of Silage". Marlow, Buckinghamshire, UK: Chalcombe Publications.

Mckean, W. T. and R. S. Jacobs (1997). "Wheat Straw as a Paper Fiber Source". The Clean Washington Center, A Division of the Pacific Northwest Economic Region (PNWER), 1-55.

Mielenz, J.R. (2001). "Ethanol production from biomass: technology and commercialization status". Current Opinion in Microbiology, 4, 324-329.

Mosier, M.S., P. Hall., C.M. Ladish and M.R. Ladish (1999). "Reaction kinetics, molecular action, and mechanism of cellulolytic proteins". Advances in Biotechnological Engineering/Biotechnology, 65, 23-40.

Mukataka, S and M. Tada (1983). "Effect of agitation on enzymatic hydrolysis of cellulose in a stirred-tank reactor". Journal of Fermentation Technology, 61(6), 615-621.

Murray, R.S., J. Schiller., R.A. Srinivasan (2000). "The Probability and Statistics" $2^{\text {nd }}$ edition. McGraw-Hill Toronto, Ltd. 5, 161- 204. 
Nader, E. and J.P. Satish (1995). "Enzymatic saccharification of soybean hull-based materials". Biotechnology Progress", 11, 708-711.

Nieves, R.A., C.I. Ehrman., W.S. Adney., R.T. Elander and M.E. Himmel (1998). "Technical Communication: Survey and analysis of commercial cellulase preparations suitable for biomass conversion to ethanol". World Journal of Microbiology and Biotechnology, 14, 301- 304.

Niranjan, K., D.L.O. Smith., C.D. Rielly., J.A. Lindley and V.R. Phillips (1994). "Mixing processes for the agricultural and food materials: Part 5, Review of mixer types". Journal of Agricultural Engineering Resource, 59,145-161.

Patzek, T.W. (2004). "Thermodynamics of the corn-ethanol biofuel cycle". Critical Reviews in Plant Sciences, 23(6), 519-567.

Putsche, V. and D. Sandor (1996). "Strategic, economic, and environmental issues for transportation fuels", In Wyman, C.E. (eds), Handbook on Bioethanol: Production and Utilization, Taylor and Francis, Washington DC, 1-20.

Reese, E.T. and D.Y. Ryu (1980). "Shear inactivation of cellulose of Trichoderma reesei". Enzyme and Microbial Technology, 2, 239- 240.

Sakka, K., G. Takada., S. Karita and K. Ohmiya (1996). "Identification and characterization of cellulose-binding domains in xylanases A of Clostridium stercorarium". Annals of the New York Academy of Sciences, 782, 241-251.

Savoie, P., D.de Halleux., K. Belkacemi., G. Turcotte., P. Nadeau and J. Chiquette (1998). "Enzymatic hydrolysis of forage and straw pretreated with ammonia". Canadian Agricultural Engineering, 40, 207-212. 
Sheehan, J. and M. Himmel (1999). "Enzymes, energy, and the environment: a strategic perspective on the U.S. Department of Energy's research and development activities for bioethanol". Biotechnology Progress, 15, 817-827.

Szengyel, Z. (2000). "Ethanol from Wood: Cellulase Enzyme Preproduction". Ph.D. Thesis, Lund University, Lund, Sweden.

Tanaka, M., S. Takenawa., R. Matsuno and T. Kamikkubo (1986). "Enzymatic hydrolysis and gas liquid interface". Journal of Fermentation Technology, 55, 137-142.

Tengborg, C., M. Galbe and G. Zacchi (2000). "Influence of enzyme loading and physical parameters on the enzymatic hydrolysis of steam-pretreated softwood". Biotechnology Progress, 17, 110-117.

Walas, S.M. (1990). "Chemical Process Equipment - Selection and Design". Elsevier, 287-304.

Wood, T.M. and K.M. Bhat (1988). "Method of measuring cellulose activity", In Wood, A.W. and T.S. Kellogg (eds.), Methods in Enzymology, 160, 87-112.

Wyman, C.E. (1996). "Ethanol production from lignocellulosic biomass: overview", In Handbook on Bioethanol: Production and Utilization. C.E. Wyman (eds.), Taylor and Francis, Washington DC, 1-16.

Ye, S. and J. Cheng (2002). "Hydrolysis of lignocellulosic materials for ethanol production: a review". Bioresources Technology, 83, 1-11.

Zhang, Y.H. and R.L. Lynd (2004). "Toward an aggregated understanding of enzymatic hydrolysis of cellulose: noncomplexed cellulase systems". Biotechnology and Bioengineering, 88, 799-824. 